\title{
A Macrocyclic Ruthenium Carbene for Size-Selective Alkene Metathesis
}

\author{
Yutong Zhang and Steven T. Diver* \\ Department of Chemistry \\ University at Buffalo, the State University of New York, Buffalo, NY, 14260
}

\section{SUPPORTING INFORMATION}

\author{
Table of Contents
}

$\begin{array}{ll}\text { A. } & \text { General Information .... } \\ \text { B. } & \text { Synthesis of Macrocyclic Ru Catalyst } \\ \text { C. } & \text { Optimization of Ru1 Preparation } \\ \text { D. } & \text { Initiation Rate of Ru1 with Ethyl Vinyl Ether } \\ \text { E. } & \text { Ring-Closing Metathesis of DEDAM using Ru1 } \\ \text { F. } & \text { Homo-dimerization Kinetic Study using Ru1 } \\ \text { G. } & \text { Competition Cross Metathesis with tert-Butyl Acrylate } \\ \text { H. } & \text { Preparative Cross Olefin Metathesis } \\ \text { I. } & \text { NMR Spectra. } \\ \text { J. } & \text { References }\end{array}$ 


\section{A. General Information}

Unless otherwise stated, reactions were conducted with oven-dried glassware under an atmosphere of nitrogen or argon. Solvent was passed through alumina and Q5 (Anhydrous Engineering solvent purifier) and stored under inert atmosphere. The Grubbs Ru carbene catalysts (HG1, HG2 and Ru C590) were obtained from Umicore and used as received. All reagents were used as received unless otherwise specified. Flash chromatography was carried out on untreated silica gel 60 from Sorbtech Technologies Inc (230 - 400 mesh) under air pressure. Thin layer chromatography (TLC) was performed on glass-backed silica plates (F254, 250 micron thickness, EMD Millipore), visualized with UV light or potassium permanganate. UV-Vis kinetics were obtained using a Varian Instruments Cary 300 Bio UV-Vis spectrophotometer running Cary WinUV software. ${ }^{1} \mathrm{H}$ NMR and ${ }^{13} \mathrm{C}$ NMR spectra were recorded at $300,400,500,750$ or $800 \mathrm{MHz}$ using Varian Mercury 300, Inova 400, Inova 500, Inova 750 and Bruker AVANCE III 800 instruments, respectively. ${ }^{1} \mathrm{H}$ NMR chemical shifts are reported in ppm relative to the solvent used $\left(\mathrm{CDCl}_{3}{ }^{1} \mathrm{H}: 7.26 \mathrm{ppm} ;{ }^{13} \mathrm{C}: 77 \mathrm{ppm}\right.$ and DMSO-d $6{ }^{1} \mathrm{H}: 2.50 \mathrm{ppm} ;{ }^{13} \mathrm{C}: 39.5$ ppm). Coupling constants $(\mathrm{J})$ are reported in $\mathrm{Hertz}(\mathrm{Hz})$ and multiplicities are abbreviated as singlet (s), broad singlet (br s), doublet (d), doublet of doublets (dd), triplet (t), triplet of doublets (td), and multiplet $(\mathrm{m})$. Infrared spectra were recorded using a Perkin Elmer Spectrum Two FTIR-ATR.

\section{B. Synthesis of Macrocyclic Ru Catalyst}
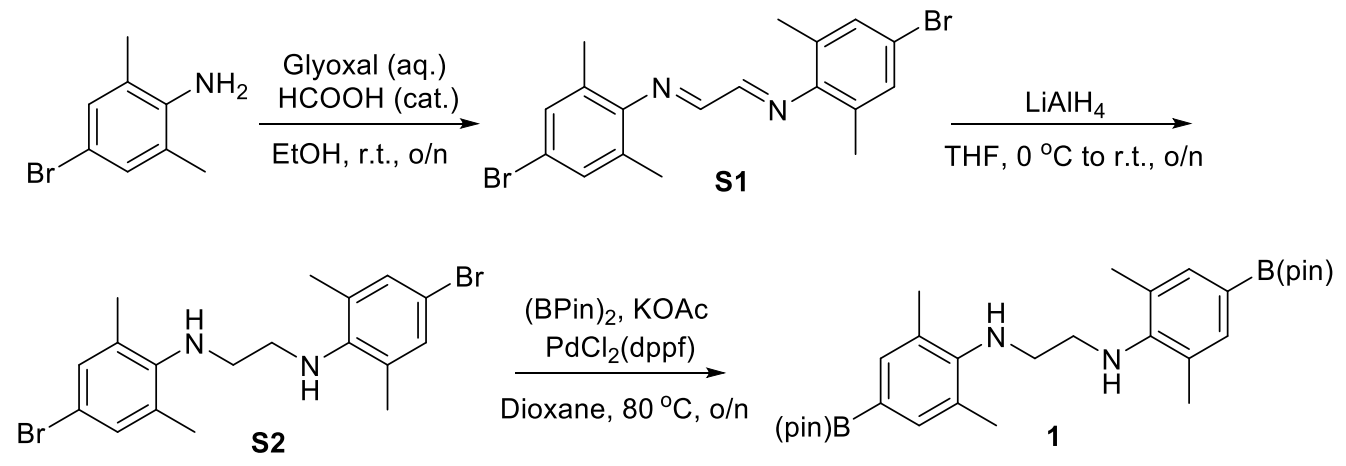

\section{N,N'-Bis(2,6-dimethyl-4-bromophenyl)ethylenediimine S1}

In a $1 \mathrm{~L}$ round bottom flask equipped with magnetic stir bar, $20 \mathrm{~g}$ of 4-bromo-2,6dimethylaniline (100 mmol, 1.0 equiv) was dissolved in $150 \mathrm{~mL}$ of ethanol. $23 \mathrm{~mL}$ of $40 \%$ weight glyoxal aqueous solution ( $200 \mathrm{mmol}, 2.0$ equiv) was added, followed by $5 \mathrm{~mL}$ of formic acid. The reaction was allowed to stir at room temperature overnight. The formed bright yellow precipitate was filtered out, then washed with ethanol and concentrated in vacuo. The crude product $(21.8 \mathrm{~g}, 99 \%)$ was used in next step without further purification. 
${ }^{1} \mathrm{H}$ NMR $\left(300 \mathrm{MHz}, \mathrm{CDCl}_{3}\right.$, ppm): $\delta 8.07$ (s, 2H), 7.24 (s, 4H), $2.15(\mathrm{~s}, 12 \mathrm{H})$. NMR spectra match those reported in literature. ${ }^{1}$

\section{N,N'-Bis(2,6-dimethyl-4-bromophenyl)ethanediamine S2}

In an oven-dried $1 \mathrm{~L}$ round bottom flask equipped with magnetic stir bar, $16 \mathrm{~g}$ of $\mathbf{S 1}$ (38 $\mathrm{mmol}, 1.0$ equiv) was dissolved in $200 \mathrm{~mL}$ of anhydrous THF under nitrogen. The solution was cooled to $0^{\circ} \mathrm{C}$ with ice/water bath and $2.9 \mathrm{~g}$ of $\mathrm{LiAlH}_{4}(76 \mathrm{mmol}, 2.0$ equiv) was slowly added. The mixture was allowed to warm up to room temperature and stirred overnight. The reaction was diluted with diethyl ether and cooled down to $0{ }^{\circ} \mathrm{C}$, then quenched by sequential addition of $2.9 \mathrm{~mL}$ of DI water, $2.9 \mathrm{~mL}$ of $15 \% \mathrm{NaOH}$ aqueous solution, and $8.7 \mathrm{~mL}$ of DI water. The mixture was allowed to warm to room temperature and stirred for 15 minutes before addition of anhydrous magnesium sulfate. The mixture was stirred for another 15 minutes, then filtered and concentrated in vacuo to obtain $\mathbf{S 2}$ as light brown solid. The crude product $(14.8 \mathrm{~g}, 91 \%)$ was used without further purification. ${ }^{1} \mathrm{H}$ NMR (300 $\mathrm{MHz}, \mathrm{CDCl}_{3}, \mathrm{ppm}$ ): $\delta 7.12$ (s, 4H), 3.33 (br s, 2H), 3.13 (s, 4H), 2.24 (s, 12H). NMR spectra match those reported in literature. ${ }^{1}$

\section{$\mathrm{N}, \mathrm{N}$ '-bis(2,6-dimethyl-4-(4,4,5,5-tetramethyl-1,3,2-dioxaborolan-2-yl)phenyl)ethane- 1,2-diamine 1}

Adapted from a previously published procedure. ${ }^{2}$ An $500 \mathrm{~mL}$ oven-dried Schlenk flask equipped with magnetic stir bar was evacuated under high vacuum and backfilled with nitrogen three times. $200 \mathrm{~mL}$ of dioxane was added and degassed with freeze-pump-thaw method twice. Then $14.8 \mathrm{~g}$ of $\mathbf{S 2}$ (35.0 mmol, 1.0 equiv), $19.4 \mathrm{~g}$ of bis(pinacolato)diboron (76 mmol, 2.2 equiv), $20.6 \mathrm{~g}$ of KOAc (210 mmol, 6.0 equiv) and $1.8 \mathrm{~g}$ of $\mathrm{PdCl}_{2}$ (dppf) were sequentially added under nitrogen. The reaction was then immersed into a pre-heated oil bath and stirred at $80{ }^{\circ} \mathrm{C}$ overnight. The solvent was removed in vacuo to give a black gooey mixture, which was purified by silica gel flash chromatography $0-20 \%$ gradient ethyl acetate/hexanes as eluent, then concentrated in vacuo. The product was further recrystallized with $250 \mathrm{~mL}$ of $20 \%$ ethyl acetate/hexanes to give $12.2 \mathrm{~g}(67 \%)$ of diamine 1 as a colorless crystalline solid. mp: $264-266{ }^{\circ} \mathrm{C}$. Analytical TLC ( $10 \%$ ethyl acetate/hexanes) $\mathrm{Rf}=0.21$. ${ }^{1} \mathrm{H}$ NMR $\left(400 \mathrm{MHz} \mathrm{CDCl}_{3}, \mathrm{ppm}\right) \delta 7.46(\mathrm{~s}, 4 \mathrm{H}), 3.54(\mathrm{~s}, 2 \mathrm{H})$, $3.27(\mathrm{~s}, 4 \mathrm{H}), 2.28(\mathrm{~s}, 12 \mathrm{H}), 1.33\left(\mathrm{~s}, 24 \mathrm{H} .{ }^{13} \mathrm{C} \mathrm{NMR}\left(75 \mathrm{MHz}, \mathrm{CDCl}_{3}, \mathrm{ppm}\right) \delta 149.12\right.$, $135.92,127.80,83.59,48.61,24.96,18.74$. The $\mathrm{sp}^{2}-\mathrm{C}$ bonded to boron was not seen, possibly due to quadrupolar relaxation. ${ }^{11} \mathrm{~B} \mathrm{NMR}\left(128 \mathrm{MHz}, \mathrm{CDCl}_{3}\right) \delta 31.30$. IR (neat, $\mathrm{cm}^{-}$ 1) $2700,2650,1610,1290,1464,1181,850,767,702$. HR-ESI MS: m/z calculated for $[\mathrm{M}]^{+} \mathrm{C}_{30} \mathrm{H}_{48} \mathrm{~N}_{2} \mathrm{O}_{2} \mathrm{~B}_{2}$ 522.3794, found 522.3779 .
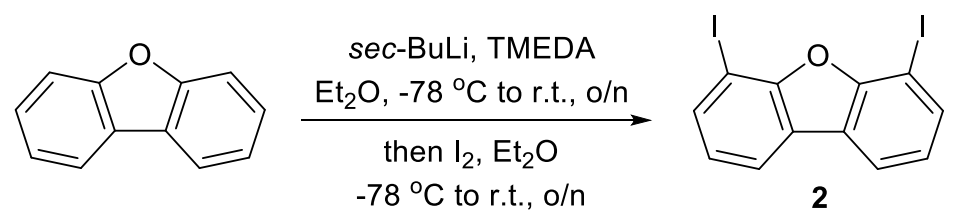

\section{4,6-Diiododibenzofuran 2}

In an oven-dried $1 \mathrm{~L}$ round bottom flask equipped with magnetic stir bar, $5 \mathrm{~g}$ of dibenzofuran (29.9 mmol, 1.0 equiv), $13.5 \mathrm{~mL}$ of TMEDA ( $89.2 \mathrm{mmol}, 3.0$ equiv), and 300 
$\mathrm{mL}$ of diethyl ether were added under nitrogen and cooled to $-78^{\circ} \mathrm{C}$. Then, $85 \mathrm{~mL}$ of secBuLi (118.9 mmol, 4.0 equiv, $1.4 \mathrm{M}$ in cyclohexane) was added dropwise via syringe. The reaction mixture was allowed to reach room temperature and stirred for $24 \mathrm{~h}$ before cooling it back to $-78{ }^{\circ} \mathrm{C}$. Then $26.6 \mathrm{~g}$ of iodine (104 mmol, 3.5 equiv) in $150 \mathrm{~mL}$ of anhydrous diethyl ether was added dropwise via syringe. The mixture was allowed to reach room temperature and stirred for another $24 \mathrm{~h}$. The reaction was quenched with $200 \mathrm{~mL}$ of $30 \% \mathrm{NaHSO}_{3}$ aqueous solution. Two layers were separated and the aqueous layer was extracted with $150 \mathrm{~mL}$ of $\mathrm{Et}_{2} \mathrm{O}$. The organic layers were combined, followed by washing with $150 \mathrm{~mL}$ of $30 \% \mathrm{NaHSO}_{3}$ solution and $150 \mathrm{~mL}$ of DI water. The crude was concentrated in vacuo and recrystallized with $200 \mathrm{~mL}$ of $30 \%$ ethyl acetate/hexanes to give the $11.6 \mathrm{~g}(93 \%)$ of dibenzofuran 2 as beige crystalline solid. ${ }^{1} \mathrm{H}$ NMR $(300 \mathrm{MHz}$, $\left.\mathrm{CDCl}_{3}, \mathrm{ppm}\right): \delta 7.87(\mathrm{~m}, 4 \mathrm{H}), 7.14(\mathrm{t}, \mathrm{J}=6.8 \mathrm{~Hz}, 2 \mathrm{H})$. Data matches those reported in literature. ${ }^{3}$
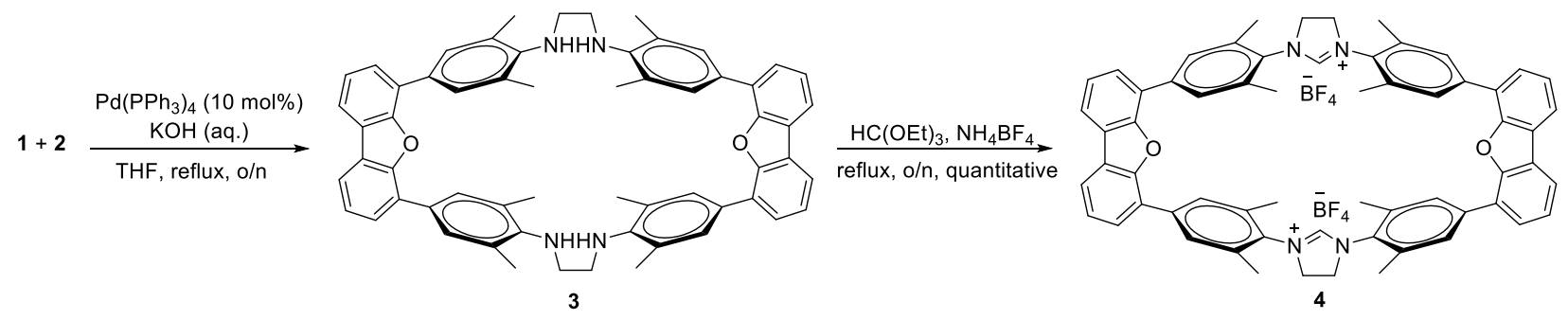

Tetra-amine Macrocycle 3

An oven-dried $500 \mathrm{~mL}$ round bottom flask equipped with magnetic stir bar was evacuated under high vacuum and backfilled with nitrogen three times. $1.15 \mathrm{~g}$ of $1(2.2 \mathrm{mmol}, 1.0$ equiv), $928 \mathrm{mg}$ of 2 (2.2 mmol, 1.0 equiv) and $133.5 \mathrm{~mL}$ of THF were added sequentially. $13.2 \mathrm{~mL}$ of $2 \mathrm{M} \mathrm{KOH}$ aqueous solution ( $26.4 \mathrm{mmol}, 12.0$ equiv) was sparged with nitrogen for 5 minutes and added into the solution, followed by $254 \mathrm{mg}$ of $\mathrm{Pd}\left(\mathrm{PPh}_{3}\right)_{4}(0.22 \mathrm{mmol}$, 0.1 equiv). Then reaction was then immersed into a pre-heated oil bath and stirred at 80 ${ }^{\circ} \mathrm{C}$ for $24 \mathrm{~h}$. Magnesium sulfate was added after the reaction reached room temperature. The mixture was filtered and concentrated in vacuo. The crude was purified by flash chromatography with $0.5 \% \mathrm{MeOH} / \mathrm{CH}_{2} \mathrm{Cl}_{2}$ as eluent to give $467 \mathrm{mg}$ ( $49 \%$ yield) of macrocycle 3. Mp: $300-310{ }^{\circ} \mathrm{C}$ (decomposed). Analytical TLC (40\% ethyl acetate/hexanes) $\mathrm{Rf}=0.22 .{ }^{1} \mathrm{H}$ NMR $\left(500 \mathrm{MHz}, \mathrm{CDCl}_{3}, \mathrm{ppm}\right) \delta 7.92(\mathrm{~d}, \mathrm{~J}=7.7 \mathrm{~Hz}, 4 \mathrm{H})$, $7.68(\mathrm{~s}, 8 \mathrm{H}), 7.64(\mathrm{~d}, \mathrm{~J}=7.5 \mathrm{~Hz}, 4 \mathrm{H}), 7.42(\mathrm{t}, \mathrm{J}=7.6 \mathrm{~Hz}, 4 \mathrm{H}), 3.70(\mathrm{~s}, 4 \mathrm{H}), 3.38(\mathrm{~s}, 8 \mathrm{H})$, 2.50 (s, 24H). ${ }^{13} \mathrm{C} \mathrm{NMR}\left(75 \mathrm{MHz}, \mathrm{CDCl}_{3}, \mathrm{ppm}\right) \delta 153.49,146.10,130.22,129.61,129.53$, 126.31, 125.91, 125.06, 123.30, 119.09, 49.02, 19.40. IR (neat, $\mathrm{cm}^{-1}$ ) 1604, 1481, 1426, 1395, 1348, 1322, 1245, 1199, 1180, 1109, 1059, 969, 874, 840, 772, 741, 675. HR-ESI MS: $\mathrm{m} / \mathrm{z}$ calculated for $[\mathrm{M}+\mathrm{H}]^{+} \mathrm{C}_{60} \mathrm{H}_{57} \mathrm{~N}_{4} \mathrm{O}_{2}$ 865.4476, found 865.4514 .

\section{Macrocyclic bis- $\mathrm{H}_{2}$ IMes Tetrafluoroborate 4}

In a $25 \mathrm{~mL}$ round bottom flask equipped with magnetic stir bar, $130 \mathrm{mg}$ of $3(0.15 \mathrm{mmol}$, 1.0 equiv), $35 \mathrm{mg}$ of ammonium tetrafluoroborate and $4.3 \mathrm{~mL}$ of triethyl orthoformate were added sequentially. The reaction was immersed in a pre-heated oil bath and stirred at 
$120{ }^{\circ} \mathrm{C}$ for $12 \mathrm{~h}$. The reaction was diluted with $\mathrm{Et}_{2} \mathrm{O}$ and filtered to give $169 \mathrm{mg}$ (quantitative) of desired product as a light yellow solid. Mp: $340-350{ }^{\circ} \mathrm{C}$ (decomposed). Analytical TLC $\left(10 \% \mathrm{MeOH} / \mathrm{CH}_{2} \mathrm{Cl}_{2}\right) \mathrm{Rf}=0.25 .{ }^{1} \mathrm{H}$ NMR $\left(400 \mathrm{MHz}, \mathrm{DMSO}-\mathrm{d}_{6}, \mathrm{ppm}\right) \delta$ 8.99 (s, 2H), 8.30 (d, J = 7.6 Hz, 4H), $7.98(\mathrm{~s}, 8 \mathrm{H}), 7.77$ (d, J = 7.6 Hz, 4H), 7.60 (d, J = $7.6 \mathrm{~Hz}, 4 \mathrm{H}), 4.66(\mathrm{~s}, 8 \mathrm{H}), 2.59$ (s, 24H). ${ }^{13} \mathrm{C}$ NMR (101 MHz, DMSO-d 6 , ppm) $\delta 160.10$, 152.97, 137.98, 136.74, 133.36, 129.70, 128.05, 124.83, 124.51, 124.41, 121.65, 51.50, 18.21. IR (neat, $\mathrm{cm}^{-1}$ ) 1630, 1479, 1265, 1179, 1056, 871, 829, 779, 743. HR-ESI MS: $\mathrm{m} / \mathrm{z}$ calculated for $[\mathrm{M}]^{2+} \mathrm{C}_{62} \mathrm{H}_{54} \mathrm{~N}_{4} \mathrm{O}_{2} 443.2118$, found 443.2119; calculated for $\left[\mathrm{M}^{2+} \mathrm{BF}_{4}{ }^{-}\right.$ $\mathrm{C}_{62} \mathrm{H}_{54} \mathrm{BF}_{4} \mathrm{~N}_{4} \mathrm{O}_{2}$ 973.4270, found 973.4278 .
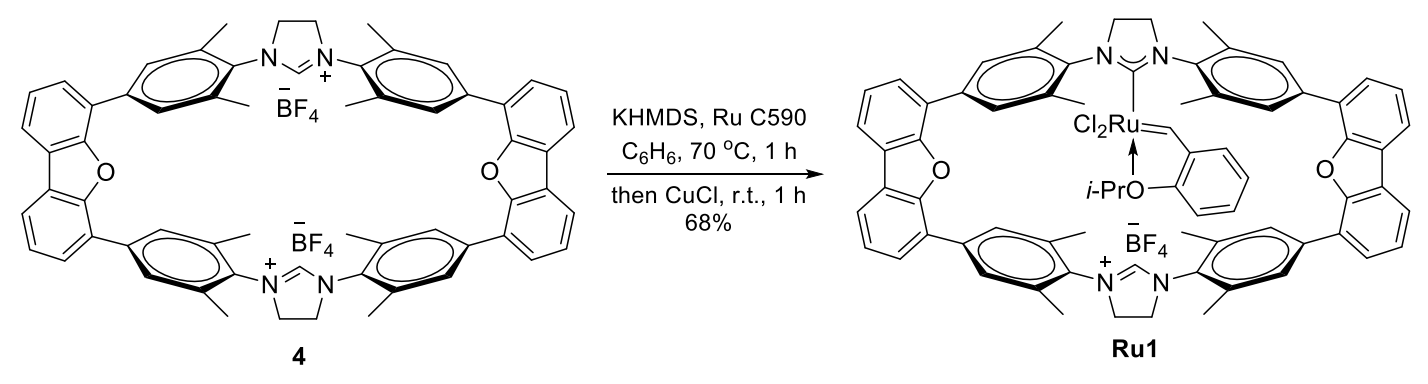

\section{Macrocyclic $\mathrm{H}_{2}$ IMes Catalyst Ru1}

In an oven-dried 1 dram vial equipped with magnetic stir bar, $30 \mathrm{mg}(0.028 \mathrm{mmol} 1.0$ equiv) of salt 4 was suspended in $260 \mu \mathrm{L}$ benzene inside argon-filled glovebox. While stirring, $300 \mu \mathrm{L}$ of $0.23 \mathrm{M} \mathrm{KHMDS}$ ( $0.069 \mathrm{mmol}, 2.5$ equiv) benzene solution was added. The resulting mixture was stirred for a few minutes, during which the light yellow suspension of changed to dark orange semi-transparent solution. Then $11.8 \mathrm{mg}(0.02$ mmol, 0.7 equiv) Grubbs catalyst $\mathbf{C} 590$ was added as solid. The reaction was then stirred at $70{ }^{\circ} \mathrm{C}$ for $1 \mathrm{~h}$. Upon cooling to room temperature, $0.042 \mathrm{mmol}$ (1.5 equiv) of $\mathrm{CuCl}$ was added under argon atmosphere and stirring continued for another hour. After that, the reaction mixture was filtered and washed with dichloromethane, concentrated in vacuo and purified via flash chromatography with $0-5 \% \mathrm{MeOH} / \mathrm{CH}_{2} \mathrm{Cl}_{2}$ as eluent to give $18 \mathrm{mg}$ of Ru1 (68\%) as an olive green solid. mp: $190-200{ }^{\circ} \mathrm{C}$ (decomposed). Analytical TLC $\left(10 \% \mathrm{MeOH} / \mathrm{CH}_{2} \mathrm{Cl}_{2}\right) \mathrm{Rf}=0.19 .{ }^{1} \mathrm{H}$ NMR $\left(500 \mathrm{MHz}, \mathrm{CDCl}_{3}, \mathrm{ppm}\right) \delta 16.25(\mathrm{~s}, 1 \mathrm{H}), 8.05-$ $7.89(\mathrm{~m}, 4 \mathrm{H}), 7.81(\mathrm{~s}, 1 \mathrm{H}), 7.71-7.53(\mathrm{~m}, 6 \mathrm{H}), 7.53-7.39(\mathrm{~m}, 5 \mathrm{H}), 7.39-7.34(\mathrm{~m}, 2 \mathrm{H})$, $7.28(\mathrm{~s}, 1 \mathrm{H}), 7.24-7.18(\mathrm{~m}, 2 \mathrm{H}), 6.96(\mathrm{~s}, 1 \mathrm{H}), 6.42(\mathrm{t}, \mathrm{J}=9.2 \mathrm{~Hz}, 2 \mathrm{H}), 5.94(\mathrm{t}, \mathrm{J}=7.4 \mathrm{~Hz}$, $1 \mathrm{H}), 4.73-4.45(\mathrm{~m}, 3 \mathrm{H}), 4.45-4.20(\mathrm{~m}, 5 \mathrm{H}), 4.02-3.92(\mathrm{~m}, 1 \mathrm{H}), 2.73(\mathrm{~s}, 3 \mathrm{H}), 2.61-$ $2.54(\mathrm{~m}, 6 \mathrm{H}), 2.53-2.43(\mathrm{~m}, 6 \mathrm{H}), 2.40(\mathrm{~s}, 3 \mathrm{H}), 2.25(\mathrm{~s}, 3 \mathrm{H}), 2.15(\mathrm{~s}, 3 \mathrm{H}), 0.84(\mathrm{~d}, \mathrm{~J}=5.9$ $\mathrm{Hz}, 3 \mathrm{H}), 0.34$ (d, J = $5.9 \mathrm{~Hz}, 3 \mathrm{H}) .{ }^{13} \mathrm{C}$ NMR $\left(201 \mathrm{MHz}, \mathrm{CDCl}_{3}, \mathrm{ppm}\right) \delta$ 297.81, 297.69, 211.09, 210.96, 158.08, 153.51, 153.47, 153.40, 153.29, 151.46, 145.22, 141.42, 140.56, $139.51,139.40,138.21,138.16,137.67,137.52,137.43,136.01,135.33,135.18,135.15$, $134.58,134.53,132.31,131.74,131.05,130.99,130.89,129.94,129.89,129.63,129.59$, $129.56,128.83,128.75,128.27,127.60,127.48,127.31,127.20,126.00,125.91,125.46$, $125.24,124.99,124.98,124.81,124.69,123.94,123.82,123.62,123.54,123.14,122.21$, $120.84,120.66,120.53,120.49,120.31,120.16,110.65,59.65,53.94,51.75,50.75$, 38.27, 35.63, 35.33, 32.04, 31.86, 31.35, 29.82, 29.40, 27.02, 26.46, 26.27, 21.56, 21.07, 20.92, 20.73, 19.54, 19.44, 19.08, 18.42, 14.24. ${ }^{19} \mathrm{~F} \mathrm{NMR}\left(470 \mathrm{MHz}, \mathrm{CDCl}_{3}, \mathrm{ppm}\right) \delta-$ 152.58. IR (neat, $\mathrm{cm}^{-1}$ ) 2923, 1628, 1478, 1428, 1258, 1182, 1055, 872, 832, 780, 745. HR-ESI MS: m/z calculated for [M] ${ }^{+} \mathrm{C}_{72} \mathrm{H}_{65} \mathrm{Cl}_{2} \mathrm{~N}_{4} \mathrm{O}_{3} \mathrm{Ru} 1205.3472$, found 1205.3493. 


\section{Optimization of Ru1 Preparation}
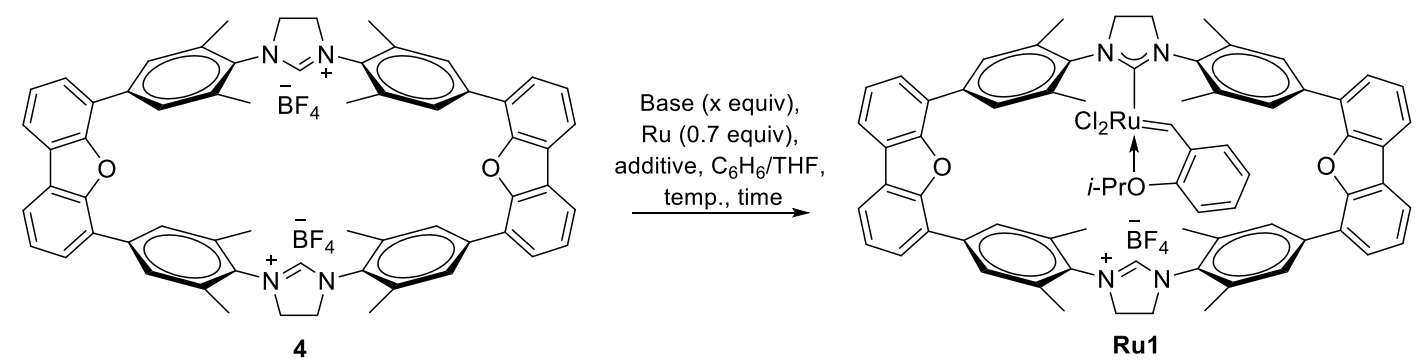

\begin{tabular}{|c|c|c|c|c|c|c|c|}
\hline Entry & Base & Equiv. & Ru & Additive & Temp. & Time & Yield \\
\hline 1 & $\mathrm{KH}$ & 5.2 & $\mathrm{HG} 1$ & None & $70^{\circ} \mathrm{C}$ & $2 \mathrm{~h}$ & -- \\
\hline 2 & $\mathrm{KOt}-\mathrm{Bu}$ & 1.0 & $\mathrm{HG} 1$ & None & $\begin{array}{c}80^{\circ} \mathrm{C} \text { then } \\
100^{\circ} \mathrm{C}\end{array}$ & $30 \mathrm{~min}$ & -- \\
\hline 3 & $\mathrm{KHMDS}$ & 1.3 & $\mathrm{HG} 1$ & None & $70^{\circ} \mathrm{C}$ & $2 \mathrm{~h}$ & $20 \%$ \\
\hline 4 & $\mathrm{KHMDS}$ & 2.5 & $\mathrm{HG} 1$ & $\mathrm{CuCl}(1.5$ equiv. $)$ & $70^{\circ} \mathrm{C}$ & $1 \mathrm{~h}$ & $51 \%$ \\
\hline 5 & KHMDS & 2.5 & $\mathrm{C} 590$ & $\mathrm{CuCl}(1.5$ equiv. $)$ & $70^{\circ} \mathrm{C}$ & $1 \mathrm{~h}$ & $68 \%$ \\
\hline
\end{tabular}

Entry 1: In an oven-dried 1 dram vial equipped with magnetic stir bar, $25 \mathrm{mg}(0.024 \mathrm{mmol}$, 1.0 equiv) of salt 4 and $5 \mathrm{mg} \mathrm{KH}(0.12 \mathrm{mmol}, 5.2$ equiv) followed by $480 \mu \mathrm{L}$ of benzene inside an argon-filled glovebox. The resulting mixture was stirred for a few minutes, then $10 \mathrm{mg}$ ( $0.017 \mathrm{mmol}, 0.7$ equiv) $\mathbf{H G} 1$ was added as solid. The reaction was then stirred at $70{ }^{\circ} \mathrm{C}$ for $2 \mathrm{~h} .{ }^{1} \mathrm{H}$ NMR showed that no Ru1 formed.

Entry 2: In an oven-dried 1 dram vial equipped with magnetic stir bar, $26.5 \mathrm{mg}(0.025$ mmol, 1.0 equiv) of salt 4 and $2.8 \mathrm{mg} \mathrm{KOt}$-Bu ( $0.025 \mathrm{mmol}, 1.0$ equiv) followed by $750 \mu \mathrm{L}$ of THF inside an argon-filled glovebox. The resulting mixture was stirred for a few minutes, then $10.7 \mathrm{mg}(0.018 \mathrm{mmol}, 0.7$ equiv) $\mathrm{HG} 1 \mathrm{in} 1 \mathrm{~mL}$ of benzene was added. The reaction was then stirred at $80^{\circ} \mathrm{C}$ for $30 \mathrm{~min} .{ }^{1} \mathrm{H}$ NMR shows no Ru1 formed. The reaction was then heated at $100^{\circ} \mathrm{C}$ for another $30 \mathrm{~min}$, which led to decomposition.

Entry 3: In an oven-dried 1 dram vial equipped with magnetic stir bar, $30 \mathrm{mg}(0.028 \mathrm{mmol}$, 1.0 equiv) of salt 4 was suspended in $400 \mu \mathrm{L}$ benzene inside an argon-filled glovebox. While stirring, $156 \mu \mathrm{L}$ of $0.23 \mathrm{M} \mathrm{KHMDS}(0.036 \mathrm{mmol}, 1.3$ equiv) benzene solution was added. The resulting mixture was stirred for a few minutes, then $12.0 \mathrm{mg}(0.02 \mathrm{mmol}, 0.7$ equiv) $\mathbf{H G} 1$ was added as solid. The reaction was then stirred at $70^{\circ} \mathrm{C}$ for $2 \mathrm{~h}$. After that, the reaction mixture was filtered and washed with dichloromethane, concentrated in vacuo and purified via flash chromatography with $0-5 \% \mathrm{MeOH} / \mathrm{CH}_{2} \mathrm{Cl}_{2}$ as eluent to give $5.3 \mathrm{mg}$ of Ru1 (20\%).

Entry 4: In an oven-dried 1 dram vial equipped with magnetic stir bar, $30 \mathrm{mg}(0.028 \mathrm{mmol}$ 1.0 equiv) of salt 4 was suspended in $260 \mu \mathrm{L}$ benzene inside an argon-filled glovebox. 
While stirring, $300 \mu \mathrm{L}$ of $0.23 \mathrm{M} \mathrm{KHMDS}(0.069 \mathrm{mmol}, 2.5$ equiv) benzene solution was added. The resulting mixture was stirred for a few minutes, then $12.0 \mathrm{mg}(0.02 \mathrm{mmol}, 0.7$ equiv) HG1 was added as solid. The reaction was then stirred at $70{ }^{\circ} \mathrm{C}$ for $1 \mathrm{~h}$. Once cooled to room temperature, $4.2 \mathrm{mg}$ of $\mathrm{CuCl}(0.042 \mathrm{mmol}, 1.5$ equiv) was added and the reaction was stirred for another $1 \mathrm{~h}$. After that, the crude mixture was filtered and washed with dichloromethane, concentrated under vacuo and purified via flash chromatography with $0-5 \% \mathrm{MeOH} / \mathrm{CH}_{2} \mathrm{Cl}_{2}$ as eluent to give $13 \mathrm{mg}$ of Ru1 (51\%).

Entry 5: In an oven-dried 1 dram vial equipped with magnetic stir bar, $30 \mathrm{mg}(0.028 \mathrm{mmol}$ 1.0 equiv) of salt 4 was suspended in $260 \mu \mathrm{L}$ benzene inside an argon-filled glovebox. While stirring, $300 \mu \mathrm{L}$ of $0.23 \mathrm{M} \mathrm{KHMDS}(0.069 \mathrm{mmol}, 2.5$ equiv) benzene solution was added. The resulting mixture was stirred for a few minutes, then $11.8 \mathrm{mg}(0.02 \mathrm{mmol}, 0.7$ equiv) $\mathrm{C} 590$ was added as solid. The reaction was then stirred at $70{ }^{\circ} \mathrm{C}$ for $1 \mathrm{~h}$. Once cooled to room temperature, $4.2 \mathrm{mg}$ of $\mathrm{CuCl}(0.042 \mathrm{mmol}, 1.5$ equiv) was added and the reaction was stirred for another $1 \mathrm{~h}$. After that, the crude mixture was filtered and washed with dichloromethane, concentrated under vacuo and purified via flash chromatography with $0-5 \% \mathrm{MeOH} / \mathrm{CH}_{2} \mathrm{Cl}_{2}$ as eluent to give $17.8 \mathrm{mg}$ of Ru1 (68\%).

\section{Initiation Rate of Ru1 with Ethyl Vinyl Ether}

A $0.5 \mathrm{mM}$ stock solution of Ru1 was prepared by dissolving $0.005 \mathrm{mmol}$ Ru1 in $10 \mathrm{~mL}$ of $\mathrm{CH}_{2} \mathrm{Cl}_{2}$ using a $10 \mathrm{~mL}$ volumetric flask inside an argon-filled glovebox. Small volumes were delivered using the appropriately sized Hamilton gas-tight syringe. UV samples were prepared by combining $600 \mu \mathrm{L}$ of the resulting stock solution with $1540 \mu \mathrm{L} \mathrm{CH}_{2} \mathrm{Cl}_{2}$ in a 3 $\mathrm{mL}$ quartz cuvette. Samples were capped with rubber septa, then removed from the glovebox. The UV-vis spectrometer's cell holder was preset to $25^{\circ} \mathrm{C}$, and the samples were allowed to equilibrate at the same temperature (about $3 \mathrm{~min}$ ). Once a stable initial absorbance was recorded, the acquisition was paused, cuvette(s) were removed from the cell holder, $860 \mu \mathrm{L}$ of ethyl vinyl ether (9 mmol, 30,000 fold excess relative to Ru1) was injected. The cuvette was gently shaken, then placed in the cell holder and acquisition was resumed. Four different trials were performed to ensure reliability.

A sample of raw absorbance $(A)$ versus time dataset is shown in Figure $\mathbf{S 1}$. The firstorder-rate constant was determined by plotting $\operatorname{Ln}\left(\left(A_{0}-A_{\text {inf }}\right) /\left(A_{t}-A_{\text {inf }}\right)\right)$ versus time, where $A_{0}$ is the initial absorbance before injection of ethyl vinyl ether; $A_{\text {inf }}$ is the final absorbance after the reaction is completed; $A_{t}$ is the absorbance at any given time point. The linear region observed before rate diminution was fit with a linear line of best fit. A sample of the processed data can be found in Figure S2. This data treatment affords the equation of the line $\operatorname{Ln}\left(\left(A_{0}-A_{\text {inf }}\right) /\left(A_{t}-A_{\text {inf }}\right)\right)=k_{o b s} \times t+C$, from which the kobs was reported for each 
catalyst. Second order rate constant was calculated from the concentration and first-order rate constant for each catalyst, as shown in Table S1.

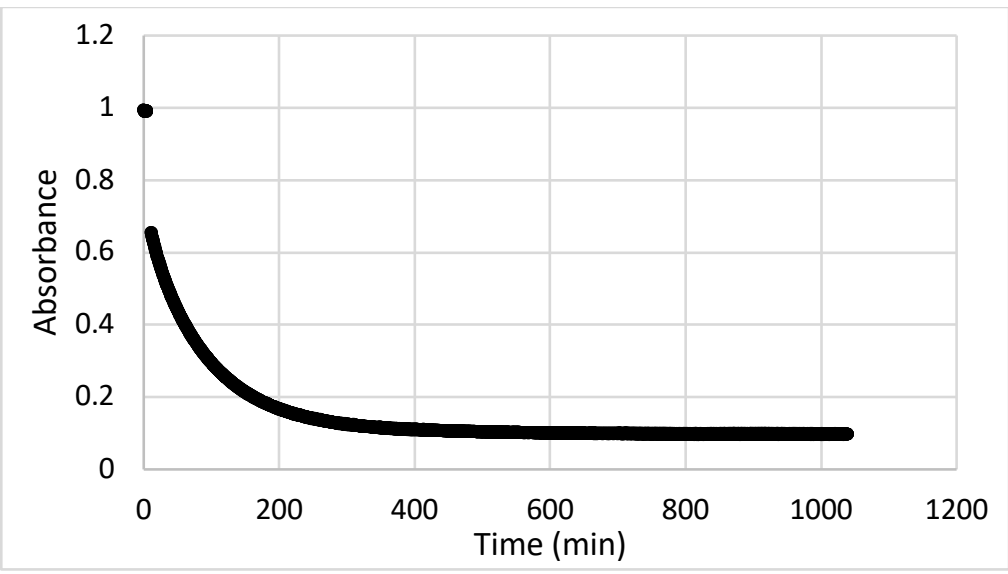

Figure S1. Raw absorbance $(\lambda=379 \mathrm{~nm})$ versus time dataset for the reaction using Ru1 $(0.1 \mathrm{mM})$ with ethyl vinyl ether $(3 \mathrm{M})$ at $25^{\circ} \mathrm{C}$ in $\mathrm{CH}_{2} \mathrm{Cl}_{2}$.

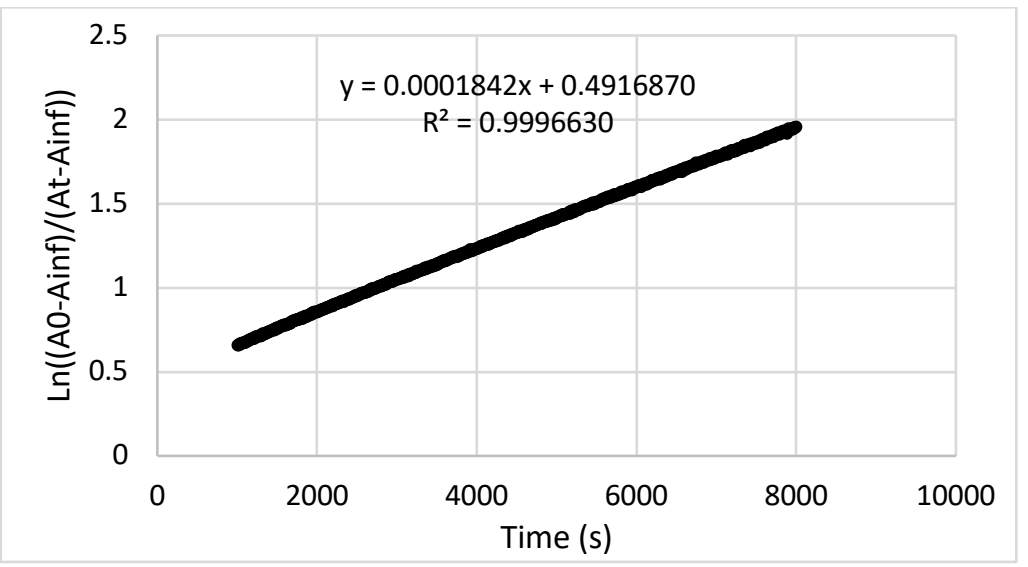

Figure S2. Processed data ( $\left.k_{\text {obs }}=1.84 \times 10^{-5} \mathrm{~s}^{-1}\right)$ for the reaction using Ru1 $(0.1 \mathrm{mM})$ with ethyl vinyl ether $(3 \mathrm{M})$ at $25^{\circ} \mathrm{C}$ in $\mathrm{CH}_{2} \mathrm{Cl}_{2}$.

Table S1. First-order and second-order rate constants of Ru1 initiation with ethyl vinyl ether. $R^{2}>0.99$ for all fits.

\begin{tabular}{|c|c|c|}
\hline Catalyst (trial \#) & $k_{\text {obs }}\left(\mathbf{s}^{-1}\right)$ & $\mathbf{k}_{\text {Init }}\left(\mathbf{s}^{-1} \mathbf{M}^{-1}\right)$ \\
\hline Ru1(1) & $1.84 \times 10^{-4}$ & $6.13 \times 10^{-5}$ \\
\hline Ru1(2) & $1.78 \times 10^{-4}$ & $5.93 \times 10^{-5}$ \\
\hline Ru1(3) & $1.86 \times 10^{-4}$ & $6.20 \times 10^{-5}$ \\
\hline Ru1(4) & $1.88 \times 10^{-4}$ & $6.27 \times 10^{-5}$ \\
\hline Average & $1.84 \times 10^{-4}$ & $6.13 \times 10^{-5}$ \\
\hline
\end{tabular}




\section{E. Ring-Closing Metathesis of DEDAM using Ru1}

Inside an argon-filled glovebox, $49.3 \mu \mathrm{L}$ of $8.12 \mathrm{mM}$ catalyst stock solution in $\mathrm{CD}_{2} \mathrm{Cl}_{2}$ $(0.0004 \mathrm{mmol}, 1 \mathrm{~mol} \%)$ was added into an oven-dried J-Young tube and diluted with 350.7 $\mu \mathrm{L} \mathrm{CD} \mathrm{Cl}_{2}$. The NMR sample was sealed with a Teflon insert screw cap and stabilized at $30{ }^{\circ} \mathrm{C}$ inside the NMR probe. Once properly locked and shimmed, an array was started immediately after injection and mixing of $9.7 \mathrm{uL}$ of DEDAM $(0.1 \mathrm{M})$. Conversion of the reaction was determined by the ratio between the integration of allylic proton in DEDAM (2.63 ppm, d, J $=7.4 \mathrm{~Hz}, 4 \mathrm{H}$ ) and that of the RCM product $(3.00 \mathrm{ppm}, \mathrm{s}, 4 \mathrm{H})$. The reaction was performed in duplicate. Time course conversion of DEDAM is shown in Table S2.

Table S2. Time course conversion of DEDAM (0.1 M) in $\mathrm{CD}_{2} \mathrm{Cl}_{2}$ using Ru1 (1 mol\%) at $30{ }^{\circ} \mathrm{C}$ in NMR tube.

\begin{tabular}{|c|c|c|c|c|c|c|c|}
\hline $\begin{array}{c}\text { Ru1 } \\
(\mathbf{1})\end{array}$ & $\begin{array}{c}\text { Time } \\
(\mathbf{s})\end{array}$ & $\begin{array}{c}\text { Conversion } \\
(\mathbf{\%})\end{array}$ & $\begin{array}{c}\text { [DEDAM] } \\
(\mathbf{M})\end{array}$ & $\begin{array}{c}\text { Ru1 } \\
\mathbf{( 2 )}\end{array}$ & $\begin{array}{c}\text { Time } \\
\mathbf{( s )}\end{array}$ & $\begin{array}{c}\text { Conversion } \\
(\mathbf{\%})\end{array}$ & $\begin{array}{c}\text { [DEDAM] } \\
(\mathbf{M})\end{array}$ \\
\hline & 869 & 0.5 & 0.0995 & & 746 & 0.9 & 0.0991 \\
\hline & 1451 & 2.2 & 0.0978 & & 1330 & 2.3 & 0.0977 \\
\hline & 2033 & 3 & 0.097 & & 1914 & 3.4 & 0.0966 \\
\hline & 2615 & 3.9 & 0.0961 & & 2498 & 4.4 & 0.0956 \\
\hline & 3197 & 4.2 & 0.0958 & & 3082 & 5.8 & 0.0942 \\
\hline & 3779 & 6.7 & 0.0933 & & 3666 & 6.8 & 0.0932 \\
\hline & 4361 & 8 & 0.092 & & 4250 & 8 & 0.092 \\
\hline & 4943 & 8.1 & 0.0919 & & 4834 & 9 & 0.091 \\
\hline & 5525 & 8.6 & 0.0914 & & 5418 & 10 & 0.09 \\
\hline & 6107 & 10 & 0.09 & & 6002 & 11.1 & 0.0889 \\
\hline & 9032 & 14.6 & 0.0854 & & 8922 & 16.4 & 0.0836 \\
\hline & 11957 & 18.4 & 0.0816 & & 11842 & 21.6 & 0.0784 \\
\hline & 14882 & 23.2 & 0.0768 & & 14762 & 26 & 0.074 \\
\hline & 17807 & 28.1 & 0.0719 & & 17682 & 30.2 & 0.0698 \\
\hline & 23657 & 35.2 & 0.0648 & & 23522 & 37.6 & 0.0624 \\
\hline & 29507 & 42 & 0.058 & & 29362 & 43.9 & 0.0561 \\
\hline & 35357 & 47.4 & 0.0526 & & 35202 & 48.8 & 0.0512 \\
\hline & 41207 & 51.8 & 0.0482 & & 41042 & 53.5 & 0.0465 \\
\hline & 68400 & 65.8 & 0.0342 & & 68400 & 68 & 0.032 \\
\hline & 134100 & 76.9 & 0.0231 & & 134100 & 76.3 & 0.0237 \\
\hline & 147600 & 78.7 & 0.0213 & & 147600 & 77.5 & 0.0225 \\
\hline 158400 & 79.4 & 0.0206 & & 158400 & 78.1 & 0.0219 \\
\hline & 218700 & 81.5 & 0.0185 & & 218700 & 81.3 & 0.0187 \\
\hline
\end{tabular}




\begin{tabular}{|l|l|l|l|l|l|l|l|}
\hline & 237600 & 82.6 & 0.0174 & & 237600 & 82.6 & 0.0174 \\
\hline & 325800 & 85.5 & 0.0145 & & 325800 & 85.5 & 0.0145 \\
\hline
\end{tabular}

The first-order rate constant of RCM reaction was determined by plotting Ln ([DEDAM]) vs time. A sample plot can be found in Figure S3. The linear region observed before rate diminution was fit with a linear line of best fit. This data treatment affords the equation of the line $L n([D E D A M])=k_{o b s} \times t+C$, from which $k_{o b s}$ was reported for each catalyst. Second order rate constant was calculated from the concentration and first-order rate constant for each catalyst, as shown in Table S3.

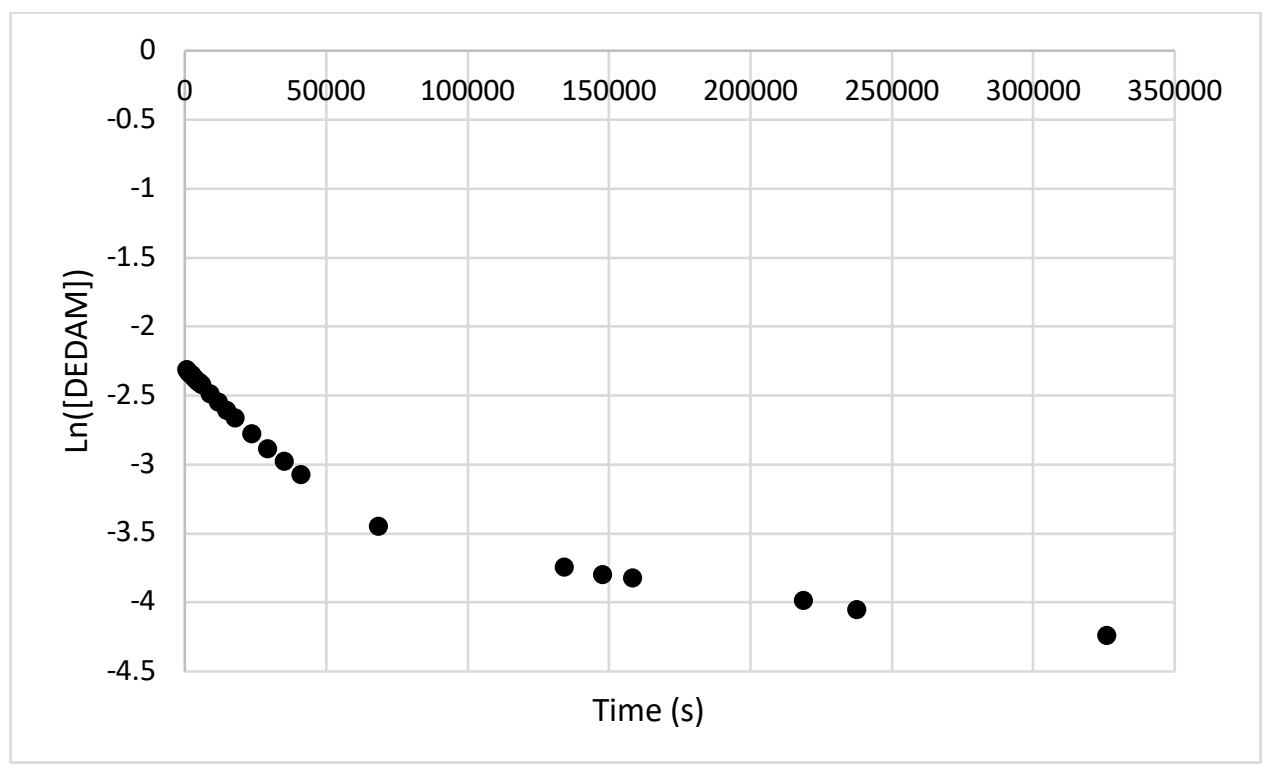

Figure S3. Ln ([DEDAM]) versus time (s) of the RCM reaction using Ru1. [DEDAM] = $0.1 \mathrm{M},[\mathrm{Ru} 1]=1 \mathrm{mM}, 30^{\circ} \mathrm{C}, \mathrm{CD}_{2} \mathrm{Cl}_{2}$, sealed NMR tube.

Table S3. First-order and second-order rate constants of RCM of DEDAM using Ru1. $\mathrm{R}^{2}>0.995$ in all cases.

\begin{tabular}{|c|c|c|}
\hline Catalyst & $\mathbf{k}_{\text {obs }}\left(\mathbf{s}^{-1}\right)$ & $\mathbf{k}_{\mathrm{RCM}}\left(\mathbf{s}^{-\mathbf{1}} \mathbf{~ M}^{-\mathbf{1}}\right)$ \\
\hline Ru1(1) & $1.83 \times 10^{-5}$ & $1.83 \times 10^{-4}$ \\
\hline Ru1(2) & $1.92 \times 10^{-5}$ & $1.92 \times 10^{-4}$ \\
\hline Average & $\mathbf{1 . 8 8 \times \mathbf { 1 0 } ^ { - 5 }}$ & $\mathbf{1 . 8 8 \times \mathbf { 1 0 } ^ { - 4 }}$ \\
\hline $\begin{array}{l}\text { Condition: [DEDAM] } \\
\text { NMR tube. }\end{array}$ & $0.1 \mathrm{M},[\mathrm{Ru}]=1 \mathrm{mM}, 30^{\circ} \mathrm{C}, \mathrm{CD}_{2} \mathrm{Cl}_{2}$, sealed \\
\hline
\end{tabular}




\section{F. Homo-dimerization Kinetic Study using Ru1}

General procedure: Inside an argon-filled glovebox, an oven-dried J-Young tube was charged with $0.3 \mathrm{mmol}$ (1 equiv) of olefin monomer in $500 \mu \mathrm{L}$ of $\mathrm{CD}_{2} \mathrm{Cl}_{2}$. 3-4 $\mu \mathrm{L}$ of 1,4dioxane was added as internal standard (s, $3.75 \mathrm{ppm}$ ). The NMR sample was sealed with a Teflon insert screw cap and stabilized at $40^{\circ} \mathrm{C}$ inside the NMR probe. Once properly locked and shimmed, an array was started immediately after injection and mixing of $0.0015 \mathrm{mmol}(0.5 \mathrm{~mol} \%)$ of Ru1 and $0.003 \mathrm{mmol}(1 \mathrm{~mol} \%)$ of $1,4-$ benzoquinone in $100 \mu \mathrm{L} \mathrm{CD}{ }_{2} \mathrm{Cl}_{2}$. The disappearance of starting olefin monomer was monitored. The concentration of olefin monomer was determined by the integral of the its terminal vinylic protons (chemical shift of those protons in each olefin is listed in Table S4) relative to the internal standard. For 1-hexene, conversion was verified with the formation of 5-decene (allylic protons, m, 2.0 ppm), see Figure S4.

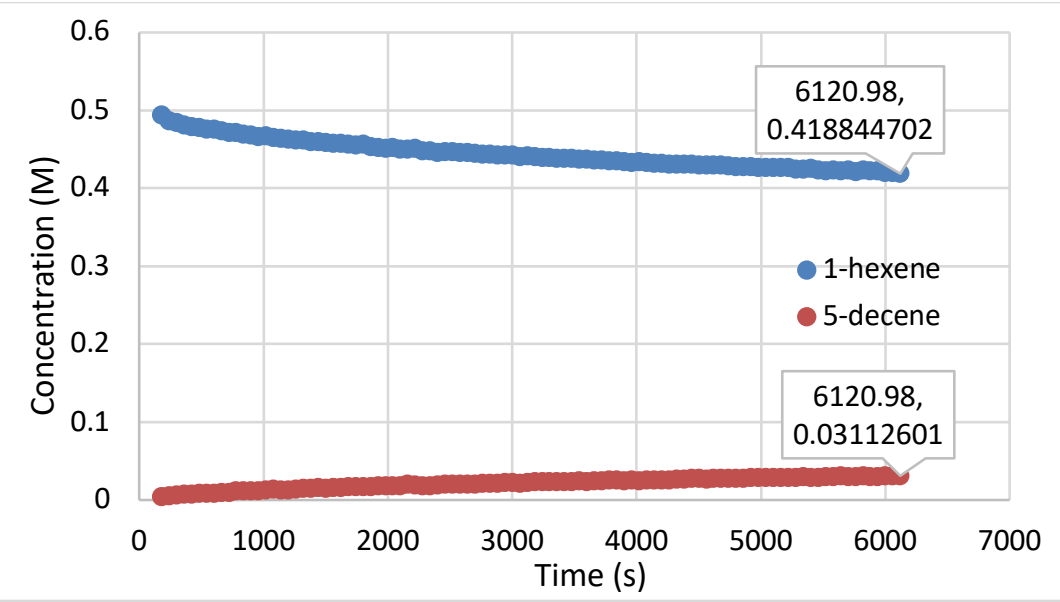

Figure S4. Concentration of 1-hexene (monomer) and 5-decene (dimer) in homodimerization using Ru1. Starting [1-hexene] $=0.5 \mathrm{M}$, Ru1 $=0.5 \mathrm{~mol} \%, 40{ }^{\circ} \mathrm{C}, \mathrm{CD}_{2} \mathrm{Cl}_{2}$, sealed NMR tube, monitored by NMR array.

Table S4. Chemical shifts of terminal vinylic protons in olefin monomers in $\mathrm{CD}_{2} \mathrm{Cl}_{2}$

\begin{tabular}{|c|c|}
\hline Olefin & Chemical shift (ppm) \\
\hline 5a & $5.00(\mathrm{~d}, 1 \mathrm{H}), 4.93(\mathrm{~d}, 1 \mathrm{H})$ \\
\hline $\mathrm{CO}_{2} \mathrm{Et} \mathbf{5 b}$ & $5.06(\mathrm{ddt}, 1 \mathrm{H}), 4.99(\mathrm{ddt}, 1 \mathrm{H})$ \\
\hline $\mathrm{SiMe}_{3}$ & $4.83(\mathrm{~m}, 2 \mathrm{H})$ \\
\hline $5 d$ & $4.93(\mathrm{~d}, 1 \mathrm{H}), 4.82(\mathrm{~d}, 1 \mathrm{H})$ \\
\hline $5 \mathbf{e}$ & $5.05(\mathrm{~d}, 1 \mathrm{H}), 4.98(\mathrm{~d}, 1 \mathrm{H})$ \\
\hline
\end{tabular}




\begin{tabular}{|cr|c|}
\hline & $\mathbf{5 f}$ & $5.11(\mathrm{~m}, 2 \mathrm{H})$ \\
\hline $\mathrm{CH}_{2} \mathrm{Ph}$ & $\mathbf{5 g}$ & $5.09(\mathrm{dd}, 1 \mathrm{H}), 5.01(\mathrm{~d}, 1 \mathrm{H})$ \\
\hline $\mathrm{CHPh}_{2}$ & $\mathbf{5 h}$ & $5.10(\mathrm{~d}, 1 \mathrm{H}), 5.01(\mathrm{~d}, 1 \mathrm{H})$ \\
\hline $\mathrm{CPh}_{3}$ & $\mathbf{5 i}$ & $5.11(\mathrm{dq}, 1 \mathrm{H}), 5.01(\mathrm{dq}, 1 \mathrm{H})$ \\
\hline
\end{tabular}

\section{G. Competition Cross Metathesis with tert-Butyl Acrylate}

General procedure: Inside an argon-filled glovebox, an oven-dried J-Young tube was charged with $0.075 \mathrm{mmol}$ (1.5 equiv) of each competing type 1 olefin in $500 \mu \mathrm{L}$ of $\mathrm{CD}_{2} \mathrm{Cl}_{2}$. 3-4 $\mu \mathrm{L}$ of 1,4-dioxane was added as internal standard (s, $3.75 \mathrm{ppm}$ ). The NMR sample was sealed with a Teflon insert screw cap. The ratio between the two olefins was confirmed to be $1: 1$ before $0.05 \mathrm{mmol}(7.3 \mu \mathrm{L}, 1.0$ equiv) of tert-butyl acrylate was added. The initial ${ }^{1} \mathrm{H}$ NMR spectrum was recorded. Then $100 \mu \mathrm{L}$ of $0.01 \mathrm{M}$ Ru1 stock solution was injected $(0.001 \mathrm{mmol}, 2 \mathrm{~mol} \%)$. The reaction was heated at $40^{\circ} \mathrm{C}$ and monitored by ${ }^{1} \mathrm{H}$ NMR. After the indicated amount of time, the final NMR spectrum was taken and the yield of each cross product was determined by their relative abundance to the 1,4dioxane, with the vinylic $\beta$-H of acrylate fragment being diagnostic signal. Chemical shift of those protons in each cross product is listed in Table S5.

Table S5. Chemical shift of the vinylic $\beta-\mathrm{H}$ of acrylate fragment in cross products between type 1 olefins and tert-butyl acrylate in $\mathrm{CD}_{2} \mathrm{Cl}_{2}$

\begin{tabular}{|c|c|}
\hline Cross product & Chemical shift (ppm) \\
\hline & $6.86(\mathrm{dt})$ \\
\hline $\mathrm{MeO}_{2} \mathrm{C}^{-}$ & $6.82(\mathrm{dt})$ \\
\hline $\mathrm{Ph}_{2} \mathrm{HC}^{-}$ & $6.74(\mathrm{dt})$ \\
\hline & $6.64(\mathrm{dt})$ \\
\hline$t-\mathrm{BuPh}_{2} \mathrm{Si}^{-}$ & $6.85(\mathrm{dt})$ \\
\hline $\mathrm{Ph}_{3} \mathrm{Si}^{-}$ & $6.94(\mathrm{dt})$ \\
\hline$(i-\mathrm{Pr})_{3} \mathrm{Si}^{-}$ & $7.00(\mathrm{dt})$ \\
\hline
\end{tabular}


7a: Light yellow oil. Analytical TLC (20\% ethyl acetate/hexanes) $\mathrm{Rf}=0.57 .{ }^{1} \mathrm{H}$ NMR $(500$ $\left.\mathrm{MHz}, \mathrm{CDCl}_{3}, \mathrm{ppm}\right) \delta 6.84(\mathrm{dt}, \mathrm{J}=15.6,7.0 \mathrm{~Hz}, 1 \mathrm{H}), 5.72(\mathrm{dt}, \mathrm{J}=15.5,1.6 \mathrm{~Hz}, 1 \mathrm{H}), 2.15$ (qd, J = 7.0, 1.6 Hz, 2H), $1.47(\mathrm{~s}, 9 \mathrm{H}), 1.45-1.37(\mathrm{~m}, 2 \mathrm{H}), 1.37-1.28(\mathrm{~m}, 2 \mathrm{H}), 0.89(\mathrm{t}, \mathrm{J}$ $=7.3 \mathrm{~Hz}, 3 \mathrm{H}) .{ }^{13} \mathrm{C} \mathrm{NMR}\left(75 \mathrm{MHz}, \mathrm{CDCl}_{3}, \mathrm{ppm}\right) \delta 166.32,148.26,123.04,80.05,31.85$, 30.32, 28.28, 22.35, 13.95. IR (neat, cm-1) 2960, 2930, 1714, 1653,1456, $1391,1366,1314,1286,1243,1219,1153,1124,1031,981,849,760$. HR-ESI MS: m/z calculated for $[\mathrm{M}+\mathrm{Na}]+\mathrm{C} 11 \mathrm{H} 20 \mathrm{NaO} 2207.1356$, found 207.1356 .

7k: NMR data agrees with literature report. ${ }^{4}$

7h: White solid. $\mathrm{mp}: 67-69^{\circ} \mathrm{C}$. Analytical TLC (10\% ethyl acetate/hexanes) $\mathrm{Rf}=0.29 .{ }^{1} \mathrm{H}$ NMR $\left(500 \mathrm{MHz}, \mathrm{CDCl}_{3}, \mathrm{ppm}\right) \delta 7.34-7.28(\mathrm{~m}, 4 \mathrm{H}), 7.28-7.18(\mathrm{~m}, 6 \mathrm{H}), 6.81(\mathrm{dt}, J=$ 15.6, 7.1 Hz, 1H), 5.78 (dt, $J=15.5,1.5 \mathrm{~Hz}, 1 \mathrm{H}), 4.11(\mathrm{t}, J=7.8 \mathrm{~Hz}, 1 \mathrm{H}), 2.95$ (td, $J=$ 7.4, $1.6 \mathrm{~Hz}, 2 \mathrm{H}), 1.47(\mathrm{~s}, 9 \mathrm{H}) .{ }^{13} \mathrm{C}$ NMR $\left(75 \mathrm{MHz}, \mathrm{CDCl}_{3}, \mathrm{ppm}\right) \delta 165.90,145.69,143.92$, 128.68, 127.91, 126.57, 124.67, 80.23, 50.44, 38.28, 28.23.IR (neat, $\mathrm{cm}^{-1}$ ) 2975, 1702, 1652, 1599, 1494, 1444, 1389, 1364, 1338, 1322, 1241, 1223, 1177, 1145, 1086, 1061, 1031, 1016, 987, 919, 855, 788, 745, 737, 696. HR-ESI MS: $\mathrm{m} / \mathrm{z}$ calculated for $[\mathrm{M}+\mathrm{Na}]^{+}$ $\mathrm{C}_{21} \mathrm{H}_{24} \mathrm{NaO}_{2}$ 331.1669, found 331.1668.

7i: White solid. $\mathrm{mp}: 102-103^{\circ} \mathrm{C}$. Analytical TLC (10\% ethyl acetate/hexanes) Rf $=0.41$. ${ }^{1} \mathrm{H}$ NMR $\left(500 \mathrm{MHz}, \mathrm{CDCl}_{3}, \mathrm{ppm}\right) \delta 7.32-7.23(\mathrm{~m}, 6 \mathrm{H}), 7.23-7.15(\mathrm{~m}, 9 \mathrm{H}), 6.72(\mathrm{dt}, \mathrm{J}=$ 15.6, 7.0 Hz, 1H), $5.72(\mathrm{dt}, J=15.6,1.6 \mathrm{~Hz}, 1 \mathrm{H}), 3.52(\mathrm{dd}, J=7.0,1.7 \mathrm{~Hz}, 2 \mathrm{H}), 1.41(\mathrm{~s}$, $9 \mathrm{H}) .{ }^{13} \mathrm{C} \mathrm{NMR}\left(75 \mathrm{MHz}, \mathrm{CDCl}_{3}, \mathrm{ppm}\right) \delta 165.76,146.76,145.30,129.32,128.09,126.37$, 125.22, 80.16, 56.55, 43.93, 28.23. IR (neat, $\mathrm{cm}^{-1}$ ) 2979, 1711, 1648, 1598, 1492, 1443, 1391, 1364, 1349, 1309, 1273, 1253, 1206, 1147, 1094, 1083, 1037, 1013, 998, 977, 911, 854, 812, 757, 741, 713, 698. HR-ESI MS: $\mathrm{m} / \mathrm{z}$ calculated for $[\mathrm{M}+\mathrm{Na}]^{+} \mathrm{C}_{27} \mathrm{H}_{28} \mathrm{NaO}_{2}$ 407.1982, found 407.1979.

7j: Colorless oil. Analytical TLC (20\% ethyl acetate/hexanes) $\mathrm{Rf}=0.53 .{ }^{1} \mathrm{H}$ NMR $(400$ $\left.\mathrm{MHz}, \mathrm{CDCl}_{3}, \mathrm{ppm}\right) \delta 7.61-7.52(\mathrm{~m}, 4 \mathrm{H}), 7.37(\mathrm{~m}, 6 \mathrm{H}), 6.96-6.82(\mathrm{dt}, J=16.0,8.0 \mathrm{~Hz}$, $1 \mathrm{H}), 5.60-5.50(\mathrm{dt}, J=16.0,2.0 \mathrm{~Hz}, 1 \mathrm{H}), 2.36-2.23(\mathrm{~d}, J=8.0 \mathrm{~Hz}, 2 \mathrm{H}), 1.40(\mathrm{~s}, 9 \mathrm{H})$, $1.08(\mathrm{~s}, 9 \mathrm{H}) .{ }^{13} \mathrm{C} \mathrm{NMR}\left(101 \mathrm{MHz}, \mathrm{CDCl}_{3}, \mathrm{ppm}\right) \delta 166.11,145.82,136.04,133.67,129.53$, 127.85, 122.47, 79.69, 28.31, 27.90, 18.77, 18.71. IR (neat, $\mathrm{cm}^{-1}$ ) 2929, 2857, 1704, 1637, 1470, 1427,1391, 1365, 1321,1294,1256, 1215,1165,1125, 1107,1045, 984, 856, 819,787, 735, 698. HR-ESI MS: $\mathrm{m} / \mathrm{z}$ calculated for $[\mathrm{M}+\mathrm{Na}]^{+} \mathrm{C}_{24} \mathrm{H}_{32} \mathrm{NaO}_{2} \mathrm{Si}$ 403.2064, found 403.2065 .

7e: White solid. mp: $93-95{ }^{\circ} \mathrm{C}$. Analytical TLC $(20 \%$ ethyl acetate/hexanes $) \mathrm{Rf}=0.46 .{ }^{1} \mathrm{H}$ NMR $\left(300 \mathrm{MHz}, \mathrm{CDCl}_{3}, \mathrm{ppm}\right) \delta 7.58-7.46(\mathrm{~m}, 6 \mathrm{H}), 7.39(\mathrm{~m}, 9 \mathrm{H}), 6.98(\mathrm{dt}, J=16.5,8.5$ $\mathrm{Hz}, 1 \mathrm{H}), 5.60(\mathrm{~d}, J=15.4 \mathrm{~Hz}, 1 \mathrm{H}), 2.52(\mathrm{~d}, J=8.6 \mathrm{~Hz}, 2 \mathrm{H}), 1.43(\mathrm{q}, J=1.8 \mathrm{~Hz}, 9 \mathrm{H}) .{ }^{13} \mathrm{C}$ NMR $\left(75 \mathrm{MHz}, \mathrm{CDCl}_{3}, \mathrm{ppm}\right) \delta 166.08,144.74,135.81,133.68,129.99,128.14,123.00$, 79.82, 28.32, 21.17. IR (neat, $\mathrm{cm}^{-1}$ ) 2925, 1699, 1638, 1426, 1389, 1368, 1327, 1259, 
1220,1153, 1130, 1108,1048, 986, 862, 788, 720, 695. HR-ESI MS: m/z calculated for $[\mathrm{M}+\mathrm{Na}]^{+} \mathrm{C}_{26} \mathrm{H}_{28} \mathrm{NaO}_{2} \mathrm{Si} 423.1751$, found 423.1752 .

7d: Colorless oil. Analytical TLC (20\% ethyl acetate/hexanes) $\mathrm{Rf}=0.60 .{ }^{1} \mathrm{H}$ NMR $(500$ $\left.\mathrm{MHz}, \mathrm{CDCl}_{3}, \mathrm{ppm}\right) \delta 7.00(\mathrm{dt}, J=15.3,8.9 \mathrm{~Hz}, 1 \mathrm{H}), 5.62(\mathrm{dt}, J=15.3,1.4 \mathrm{~Hz}, 1 \mathrm{H}), 1.77$ (dd, $J=8.9,1.4 \mathrm{~Hz}, 2 \mathrm{H}), 1.45(\mathrm{~s}, 9 \mathrm{H}), 1.12-0.95(\mathrm{~m}, 21 \mathrm{H}) .{ }^{13} \mathrm{C} \mathrm{NMR}\left(75 \mathrm{MHz}, \mathrm{CDCl}_{3}\right.$, ppm) $\delta 166.42,147.60,120.81,79.61,28.34,18.67,17.29,11.13$. IR (neat, $\mathrm{cm}^{-1}$ ) 2942, 2866, 1706, 1637, 1461, 1390,1366, 1320, 1293,1255, 1213, 1168, 1124, 1043, 985, 918, $881,856,785,753,718,676$. HR-ESI MS: $\mathrm{m} / \mathrm{z}$ calculated for $[\mathrm{M}+\mathrm{Na}]^{+} \mathrm{C}_{17} \mathrm{H}_{34} \mathrm{NaO}_{2} \mathrm{Si}$ 321.2220 , found 321.2221 .

\section{H. Preparative Cross Olefin Metathesis}

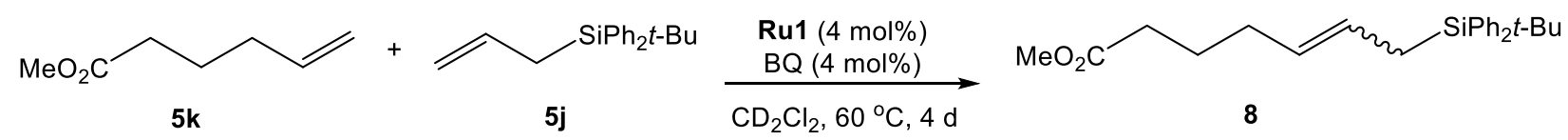

Inside an argon-filled glovebox, an oven-dried J-Young tube was charged with $21 \mu \mathrm{L}$ of methyl 5-hexenoate $(0.15 \mathrm{mmol}, 0.5$ equiv) and $45 \mu \mathrm{L}$ of allyl(tert-butyl)diphenylsilane ( $0.15 \mathrm{mmol}, 0.5$ equiv) in $500 \mu \mathrm{L} \mathrm{CD} \mathrm{Cl}_{2}$. The NMR tube was sealed with a Teflon insert cap. The ratio of the two olefins was confirmed to be $1: 1$ by ${ }^{1} \mathrm{H}$ NMR. 7.8 mg Ru1 $(0.006$ $\mathrm{mmol}, 2 \mathrm{~mol} \%$ ) was dissolved in $100 \mu \mathrm{L}$ stock solution of $0.06 \mathrm{M}$ 1,4-benzoquinone (0.006 $\mathrm{mmol}, 2 \mathrm{~mol} \%$ ) in $\mathrm{CD}_{2} \mathrm{Cl}_{2}$, then injected in the reaction mixture. The reaction was heated at $60{ }^{\circ} \mathrm{C}$ for 2 days. Another $2 \mathrm{~mol} \%$ of Ru1 and $2 \mathrm{~mol} \%$ of benzoquinone were added inside glovebox, and the NMR tube was purged with argon to remove ethylene. The reaction was terminated after heating for another 2 days. The solvent was removed under vacuo and the crude was purified by flash chromatography with $0-2 \%$ gradient ethyl acetate/hexanes as eluent to give $34 \mathrm{mg}$ of desired cross dimer 8 as light yellow oil $(60 \%)$ and $10 \mathrm{mg}$ of allyl(tert-butyl)diphenylsilane was recovered (24\%).

8: Colorless oil. Analytical TLC (20\% ethyl acetate/hexanes) $\mathrm{Rf}=0.38 .{ }^{1} \mathrm{H}$ NMR $(300 \mathrm{MHz}$, $\left.\mathrm{CDCl}_{3}, \mathrm{ppm}\right) \delta 7.69-7.52(\mathrm{~m}, 4 \mathrm{H}), 7.45-7.29(\mathrm{~m}, 6 \mathrm{H}), 5.53-5.31(\mathrm{~m}, 1 \mathrm{H}), 5.31-5.06$ $(\mathrm{m}, 1 \mathrm{H}), 3.63(\mathrm{~s}, 3 \mathrm{H}), 2.15-2.03(\mathrm{~m}, 4 \mathrm{H}), 1.89(\mathrm{q}, \mathrm{J}=7.1 \mathrm{~Hz}, 2 \mathrm{H}), 1.61-1.44(\mathrm{~m}, 2 \mathrm{H})$, $1.14-1.02(\mathrm{~m}, 9 \mathrm{H}) .{ }^{13} \mathrm{C} \mathrm{NMR}\left(75 \mathrm{MHz}, \mathrm{CDCl}_{3}, \mathrm{ppm}\right) \delta 174.34,136.15,134.72,129.42$, 129.14, 127.63, 126.86, 51.48, 33.30, 32.14, 28.00, 24.93, 18.54, 16.94. IR (neat, $\mathrm{cm}^{-1}$ ) 2929, 2856,1737,1470, 1427, 1391,1362, 1166, 1105, 998, 965, 819,736, 699. HR-ESI MS: $\mathrm{m} / \mathrm{z}$ calculated for $[\mathrm{M}+\mathrm{Na}]^{+} \mathrm{C}_{24} \mathrm{H}_{32} \mathrm{NaO}_{2} \mathrm{Si} 403.2064$, found 403.2064 .

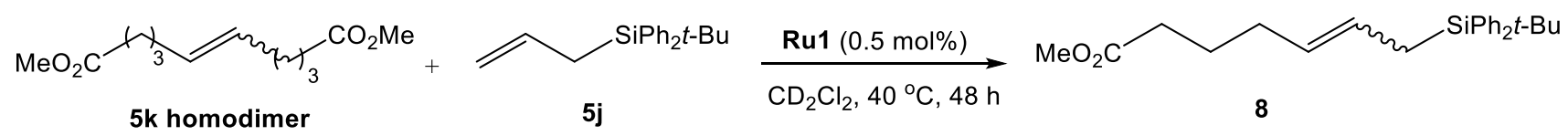


Inside an argon-filled glovebox, an oven-dried J-Young tube was charged with $40 \mu \mathrm{L}$ of 5k homodimer ( $0.15 \mathrm{mmol}, 0.5$ equiv) and $45 \mu \mathrm{L}$ of allyl(tert-butyl)diphenylsilane $(0.15$

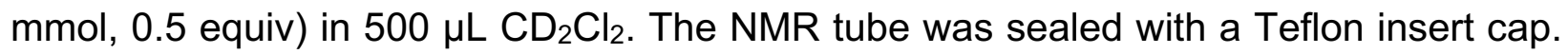
The ratio of the two olefins was confirmed to be $1: 1$ by ${ }^{1} \mathrm{H}$ NMR. $1.9 \mathrm{mg}$ Ru1 $(0.0015$ $\mathrm{mmol}, 0.5 \mathrm{~mol} \%$ ) was dissolved in $100 \mu \mathrm{L} \mathrm{CD}{ }_{2} \mathrm{Cl}_{2}$, then injected in the reaction mixture. The reaction was heated at $40{ }^{\circ} \mathrm{C}$ for $48 \mathrm{~h}$. The solvent was removed under vacuo and the crude was purified by flash chromatography with $0-2 \%$ gradient ethyl acetate/hexanes as eluent to give $39 \mathrm{mg}$ of desired cross dimer 8 as light yellow oil (68\%).

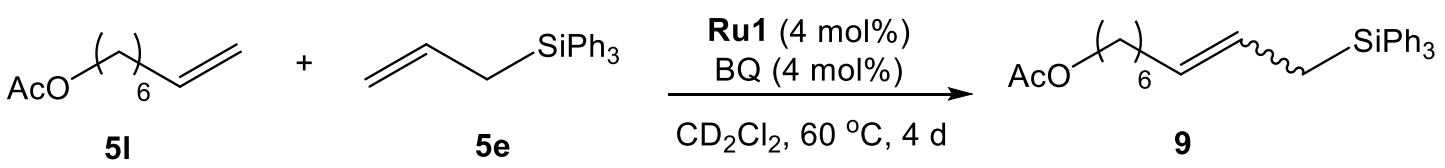

Inside an argon-filled glovebox, an oven-dried J-Young tube was charged with $28.7 \mu \mathrm{L}$ of 7-octenyl acetate $(0.15 \mathrm{mmol}, 0.5$ equiv) and $45 \mathrm{mg}$ of allyltriphenylsilane $(0.15 \mathrm{mmol}, 0.5$ equiv) in $500 \mu \mathrm{L} \mathrm{CD}_{2} \mathrm{Cl}_{2}$. The NMR tube was sealed with a Teflon insert cap. The ratio of the two olefins was confirmed to be $1: 1$ by ${ }^{1} \mathrm{H}$ NMR. $7.8 \mathrm{mg}$ Ru1 $(0.006 \mathrm{mmol}, 2 \mathrm{~mol} \%)$ was dissolved in $100 \mu \mathrm{L}$ stock solution of $0.06 \mathrm{M}$ 1,4-benzoquinone $(0.006 \mathrm{mmol}, 2 \mathrm{~mol} \%)$ in $\mathrm{CD}_{2} \mathrm{Cl}_{2}$, then injected in the reaction mixture. The reaction was heated at $60{ }^{\circ} \mathrm{C}$ for 2 days. Another $2 \mathrm{~mol} \%$ of Ru1 and $2 \mathrm{~mol} \%$ of benzoquinone were added inside glovebox, and the NMR tube was purged with argon to remove ethylene. The reaction was terminated after heating for another 2 days. The solvent was removed under vacuo and the crude was purified by flash chromatography with 0-2\% gradient ethyl acetate/hexanes as eluent to give $42 \mathrm{mg}$ of desired cross dimer 9 as colorless oil (63\%). $10 \mathrm{mg}$ of allyltriphenylsilane was recovered (22\%).

9: Colorless oil. Analytical TLC (10\% ethyl acetate/hexanes) $\mathrm{Rf}=0.12 .{ }^{1} \mathrm{H}$ NMR $(400 \mathrm{MHz}$, $\left.\mathrm{CDCl}_{3}, \mathrm{ppm}\right)$ Mixture of $E$ and $Z$ isomers, with $E / Z=4: 1 . \delta 7.61-7.48(\mathrm{~m}, 6 \mathrm{H}), 7.48-7.30$ $(\mathrm{m}, 9 \mathrm{H}), 5.48(\mathrm{dt}, J=15.3,7.6 \mathrm{~Hz}, 1 \mathrm{H}), 5.33(\mathrm{dt}, J=14.9,7.0 \mathrm{~Hz}, 1 \mathrm{H}), 4.02(\mathrm{dt}, J=14.5$, $6.7 \mathrm{~Hz}, 2 \mathrm{H}$ ), $2.34(\mathrm{t}, J=9.0 \mathrm{~Hz}, 2 \mathrm{H}), 2.11-1.99(\mathrm{~m}, 3 \mathrm{H}), 1.92(\mathrm{q}, J=6.7 \mathrm{~Hz}, 1.6 \mathrm{H}), 1.85$ $(\mathrm{d}, J=6.7 \mathrm{~Hz}, 0.4 \mathrm{H}), 1.64-1.49(\mathrm{~m}, 2 \mathrm{H}), 1.36-1.11(\mathrm{~m}, 6 \mathrm{H}) .{ }^{13} \mathrm{C} \mathrm{NMR}\left(101 \mathrm{MHz}, \mathrm{CDCl}_{3}\right.$, ppm) $E$ isomer. $\delta 171.34,135.89,134.97,131.29,129.56,127.89,124.74,64.76,32.75$, 29.63, 28.71, 28.67, 25.90, 21.15, 19.34. IR (neat, $\mathrm{cm}^{-1}$ ) 2926, 2853, 1736, 1427, 1364, $1235,1156,1110,1029,997,965,763,732,699$. HR-ESI MS: $\mathrm{m} / \mathrm{z}$ calculated for $[\mathrm{M}+\mathrm{Na}]^{+}$ $\mathrm{C}_{29} \mathrm{H}_{34} \mathrm{NaO}_{2} \mathrm{Si} 465.2220$, found 465.2222.

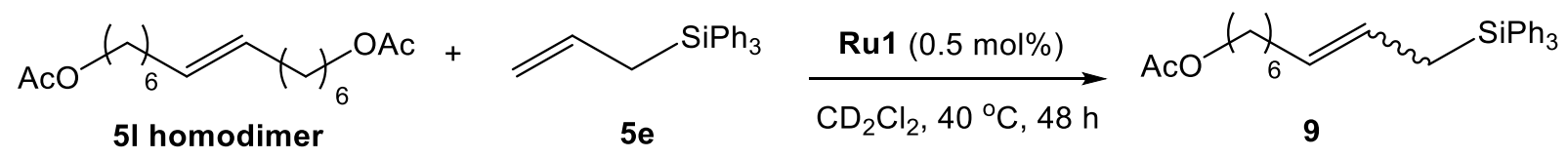

5I homodimer was prepared using commercially available HG2 from 5I. Colorless oil. Analytical TLC (20\% ethyl acetate/hexanes) $\mathrm{Rf}=0.33 .{ }^{1} \mathrm{H} \mathrm{NMR}\left(400 \mathrm{MHz} \mathrm{CDCl}_{3}, \mathrm{ppm}\right) \delta$ 
$5.47-5.20(\mathrm{~m}, J=5.7 \mathrm{~Hz}, 2 \mathrm{H}), 4.04(\mathrm{t}, J=6.7 \mathrm{~Hz}, 4 \mathrm{H}), 2.03(\mathrm{~s}, 6 \mathrm{H}), 1.97(\mathrm{t}, J=5.9 \mathrm{~Hz}$, $4 \mathrm{H}), 1.61(\mathrm{p}, J=7.9,7.0 \mathrm{~Hz}, 4 \mathrm{H}), 1.44-1.23(\mathrm{~m}, 12 \mathrm{H}) .{ }^{13} \mathrm{C} \mathrm{NMR}\left(101 \mathrm{MHz}, \mathrm{CDCl}_{3}, \mathrm{ppm}\right)$ $\delta 171.36,130.42,64.75,32.58,29.58,28.86,28.70,25.89,21.14$. IR (neat, $\mathrm{cm}^{-1}$ ) 2927, $2855,1737,1462,1365,1231,1036,968,732$. HR-ESI MS: $\mathrm{m} / \mathrm{z}$ calculated for $[\mathrm{M}+\mathrm{Na}]^{+}$ $\mathrm{C}_{18} \mathrm{H}_{32} \mathrm{NaO}_{4} 335.2193$, found 335.2193.

Inside an argon-filled glovebox, an oven-dried J-Young tube was charged with $50 \mu \mathrm{L}$ of 5 I homodimer $(0.15 \mathrm{mmol}, 0.5$ equiv $)$ and $45 \mathrm{mg}$ of allyltriphenylsilane $(0.15 \mathrm{mmol}, 0.5$ equiv) in $500 \mu \mathrm{L} \mathrm{CD}_{2} \mathrm{Cl}_{2}$. The NMR tube was sealed with a Teflon insert cap. The ratio of the two olefins was confirmed to be $1: 1$ by ${ }^{1} \mathrm{H}$ NMR. $1.9 \mathrm{mg}$ Ru1 $(0.0015 \mathrm{mmol}, 0.5 \mathrm{~mol} \%)$ was dissolved in $100 \mu \mathrm{L} \mathrm{CD}_{2} \mathrm{Cl}_{2}$, then injected in the reaction mixture. The reaction was heated at $40{ }^{\circ} \mathrm{C}$ for 48 hours. The solvent was removed under vacuo and the crude was purified by flash chromatography with $0-2 \%$ gradient ethyl acetate/hexanes as eluent to give $44 \mathrm{mg}$ of desired cross dimer 9 as colorless oil (66\%).

\section{NMR Spectra}

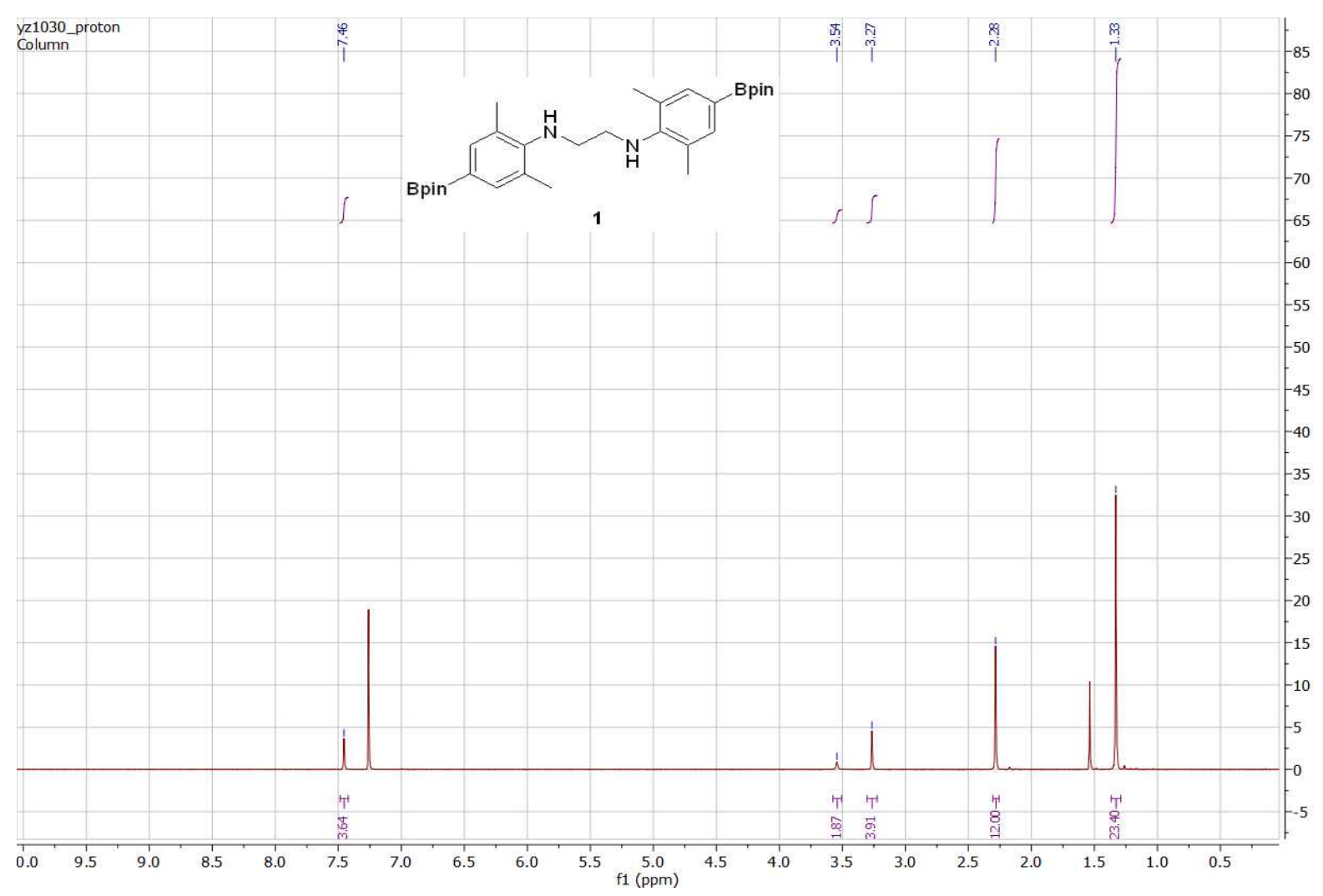



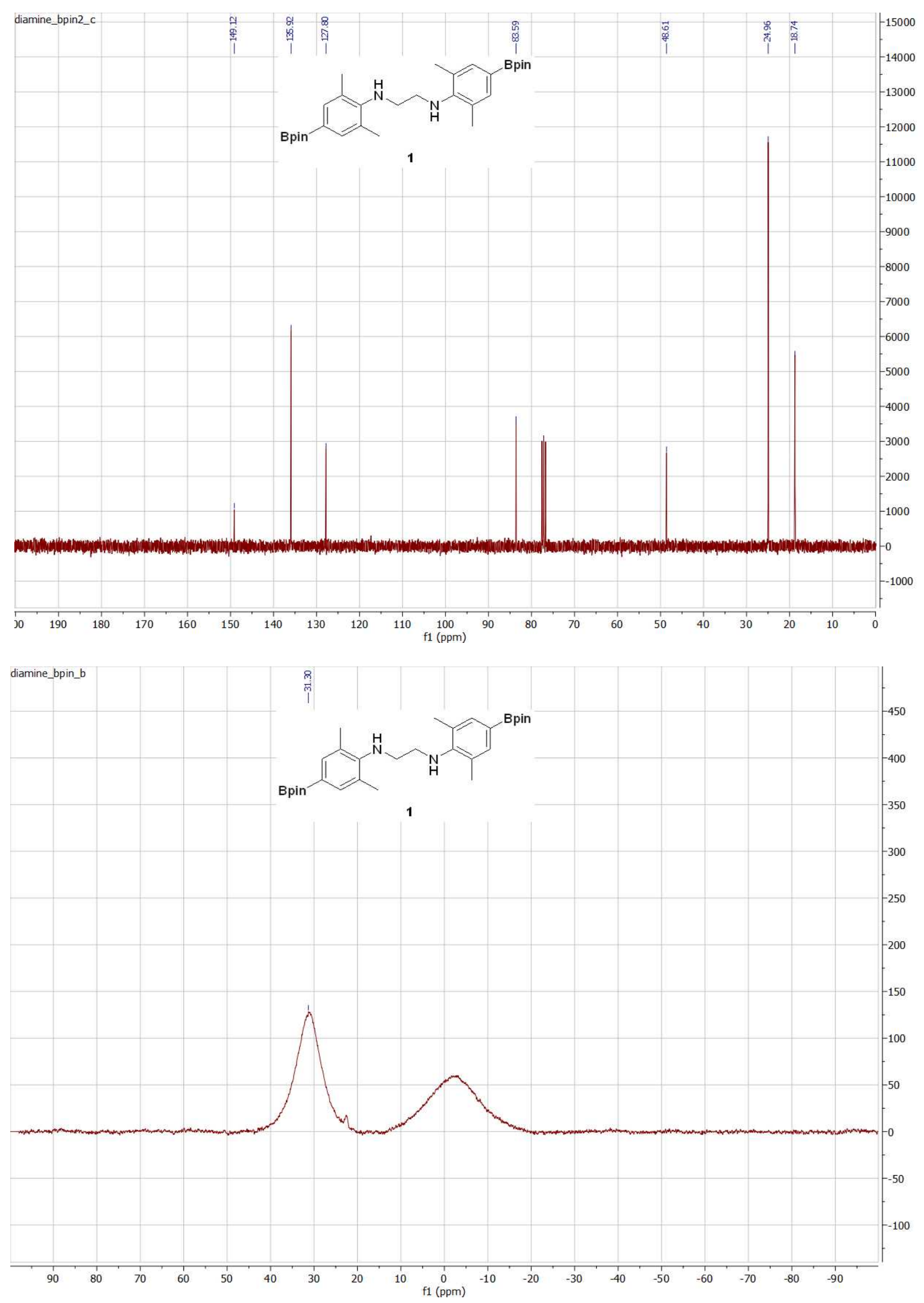

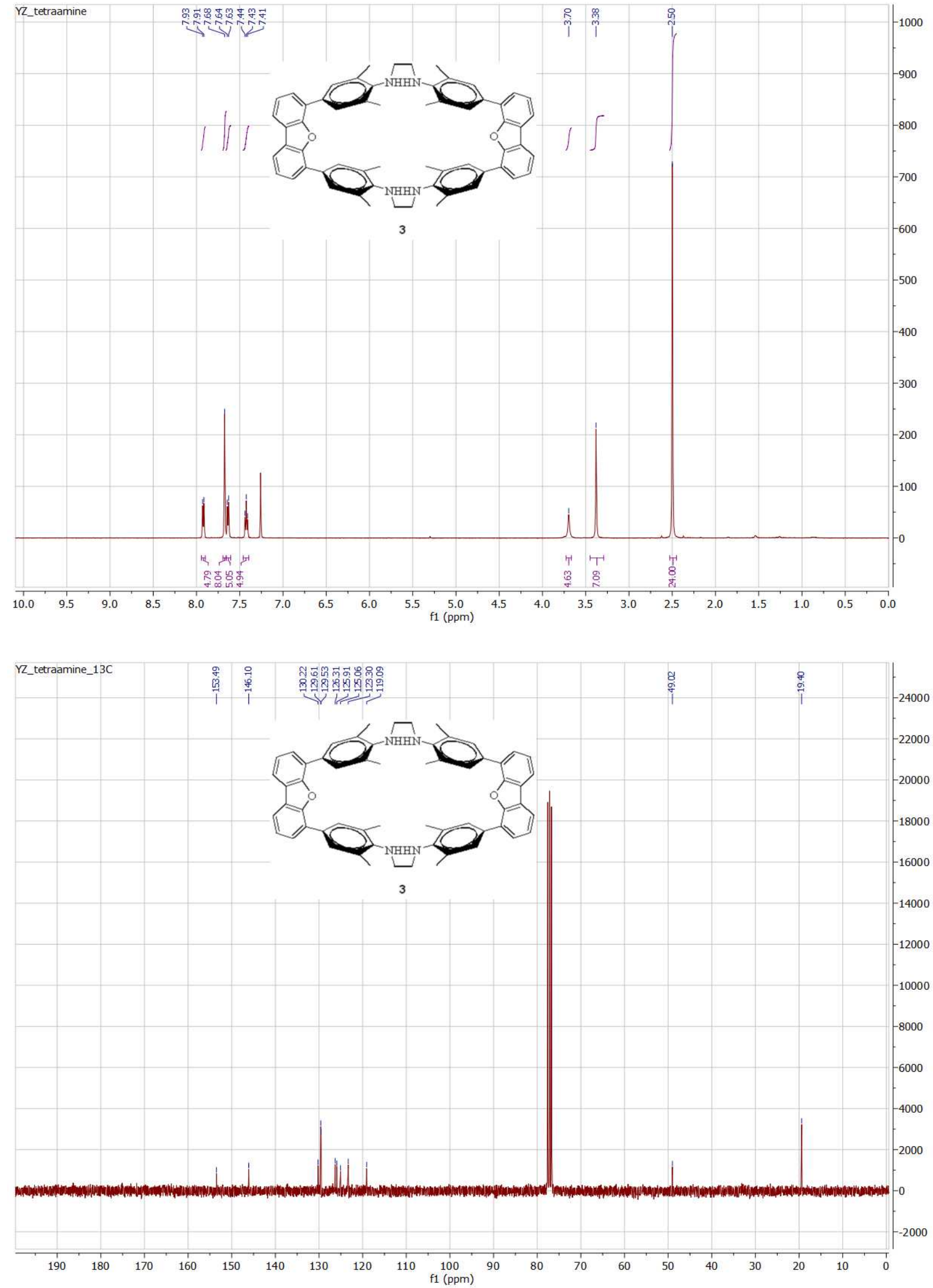


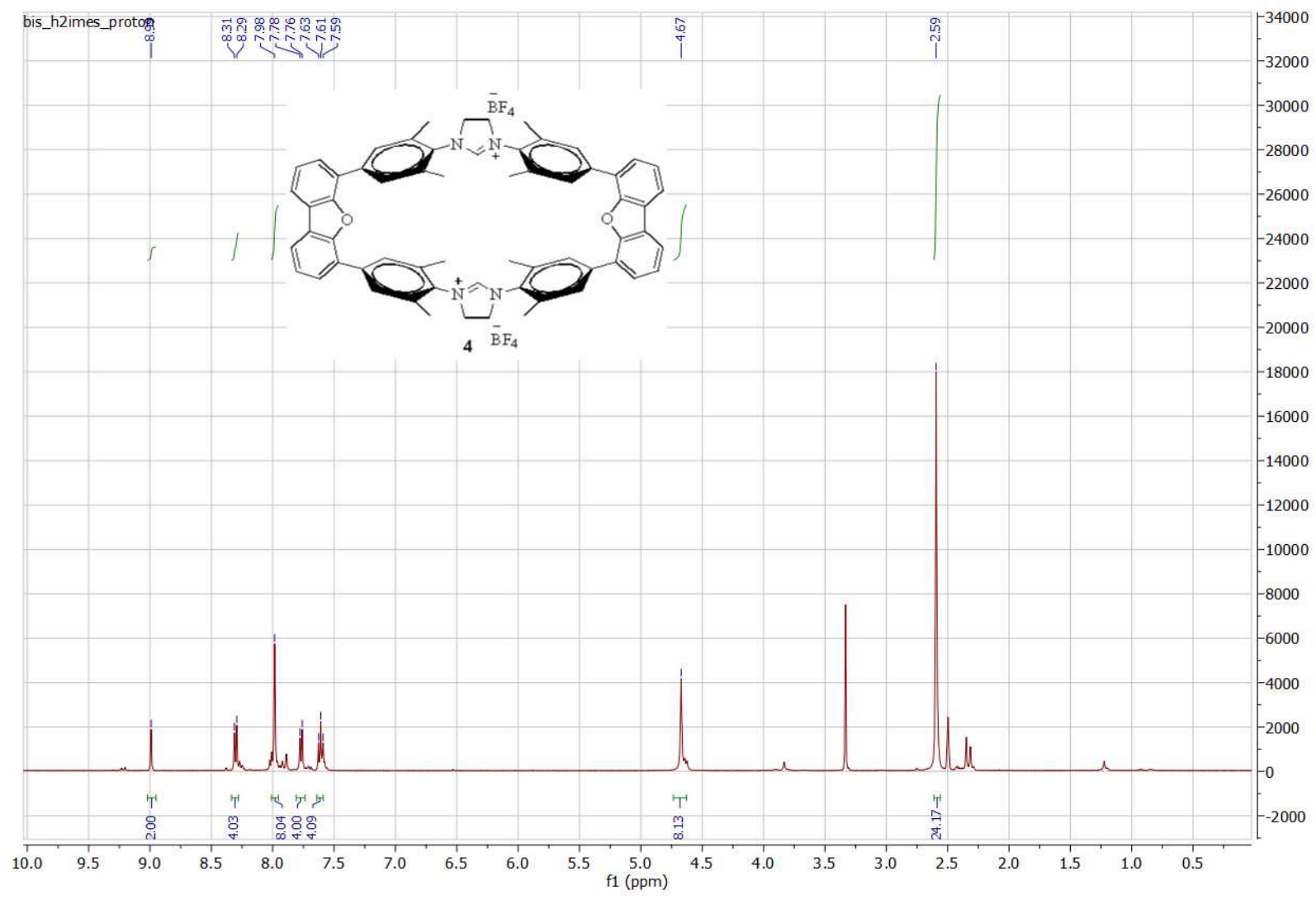



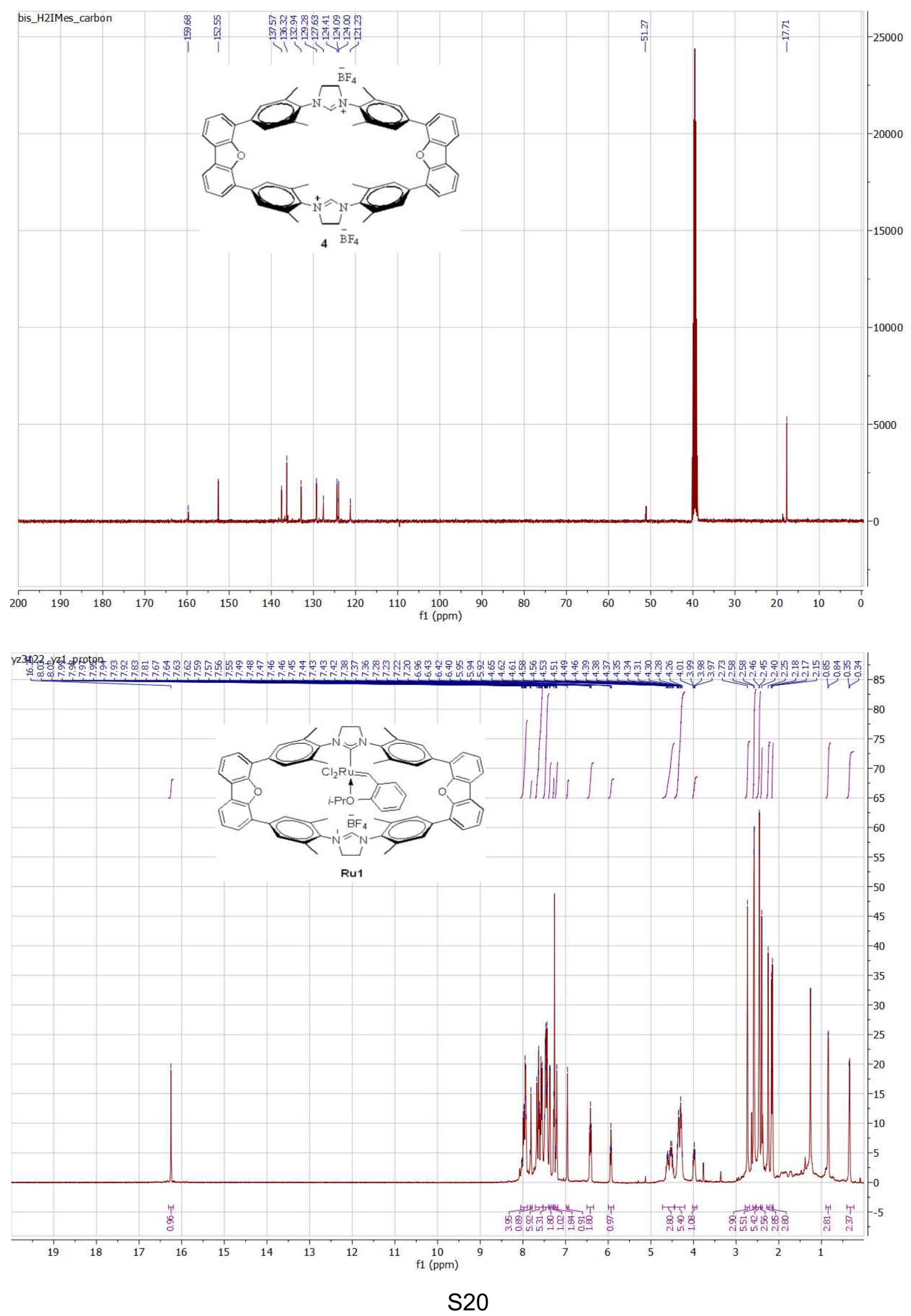


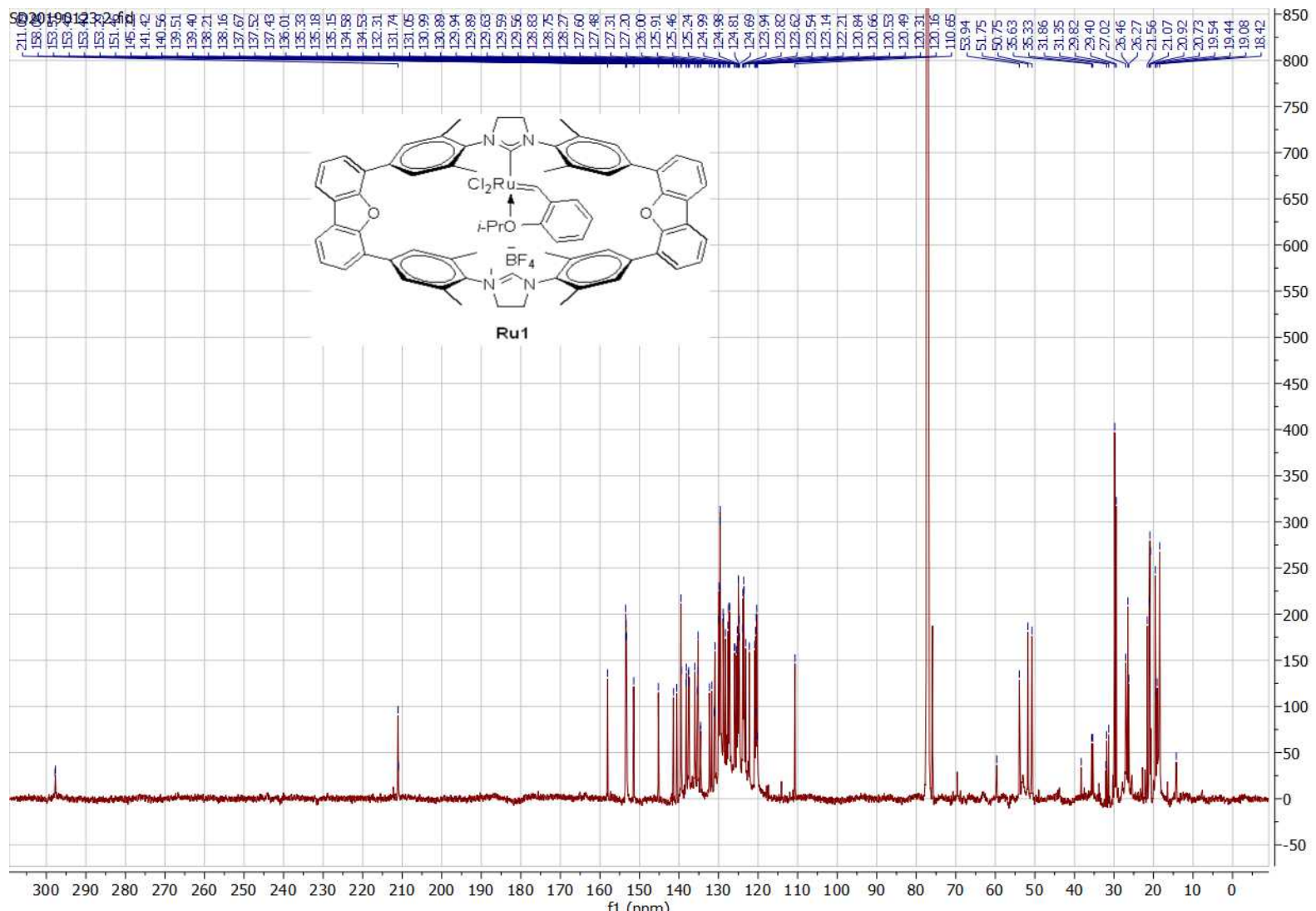

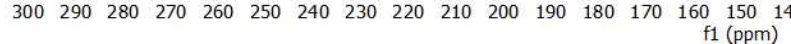

yz1_fluorine
STANDARD FLUORINE PARAMETERS
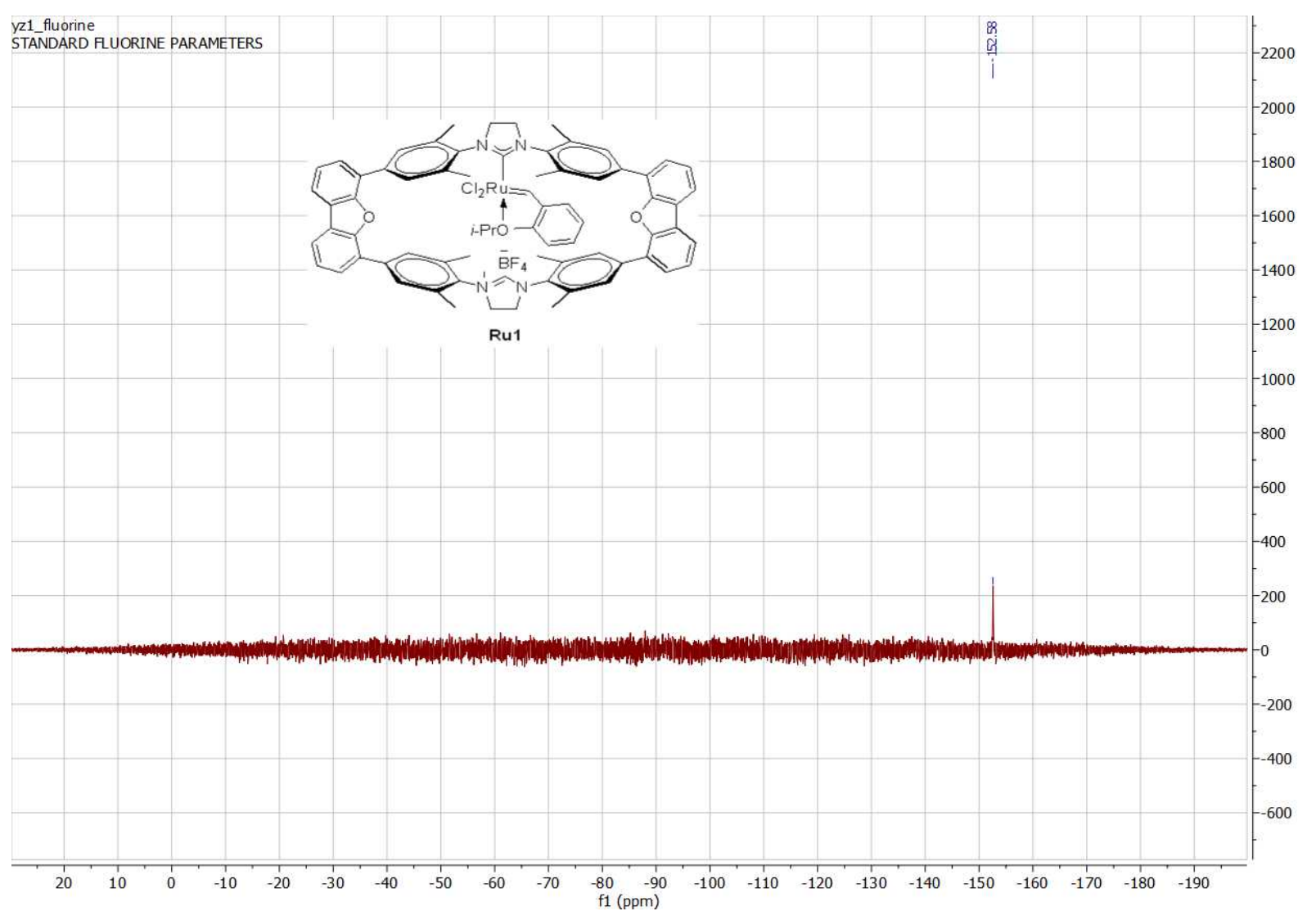

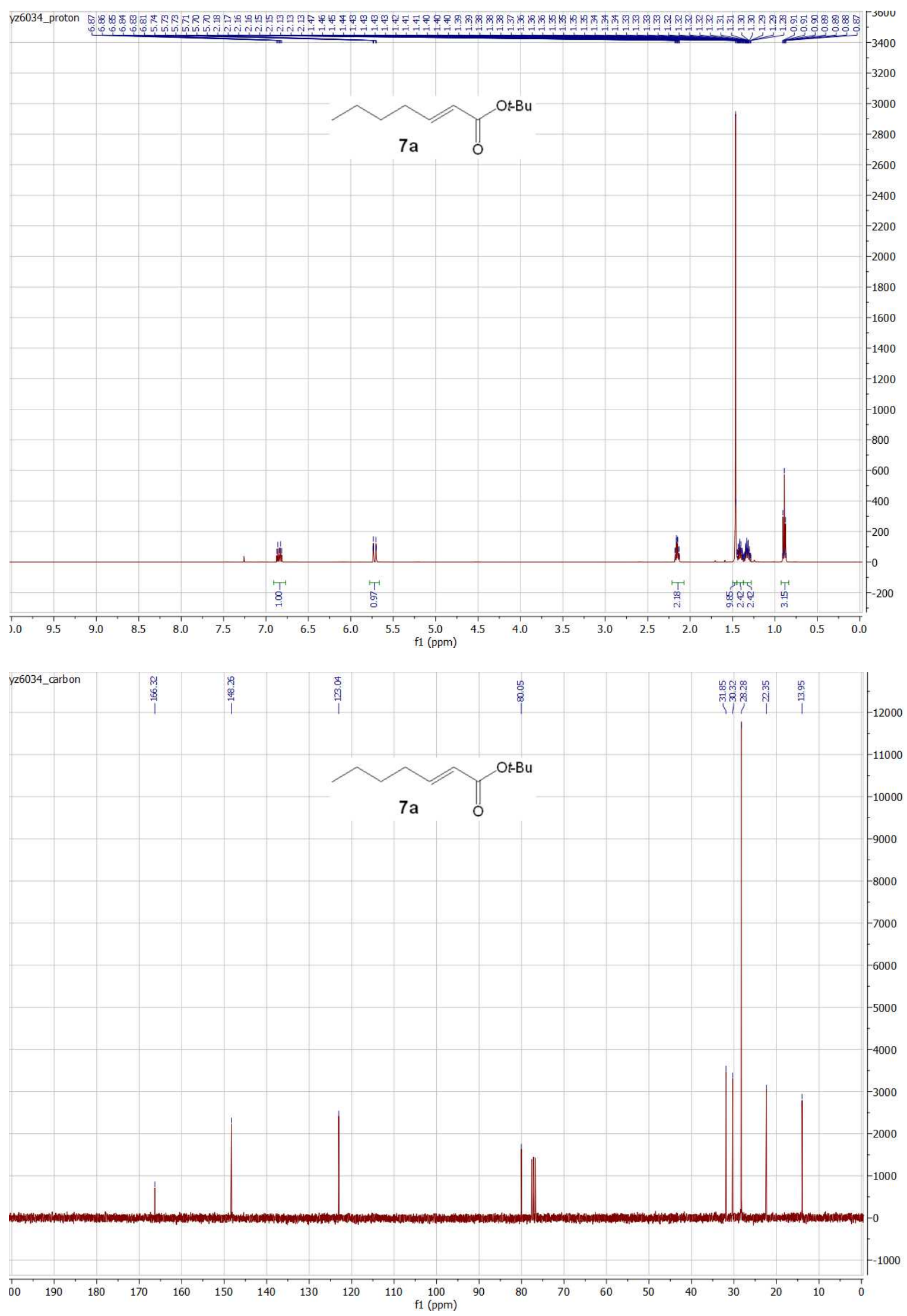


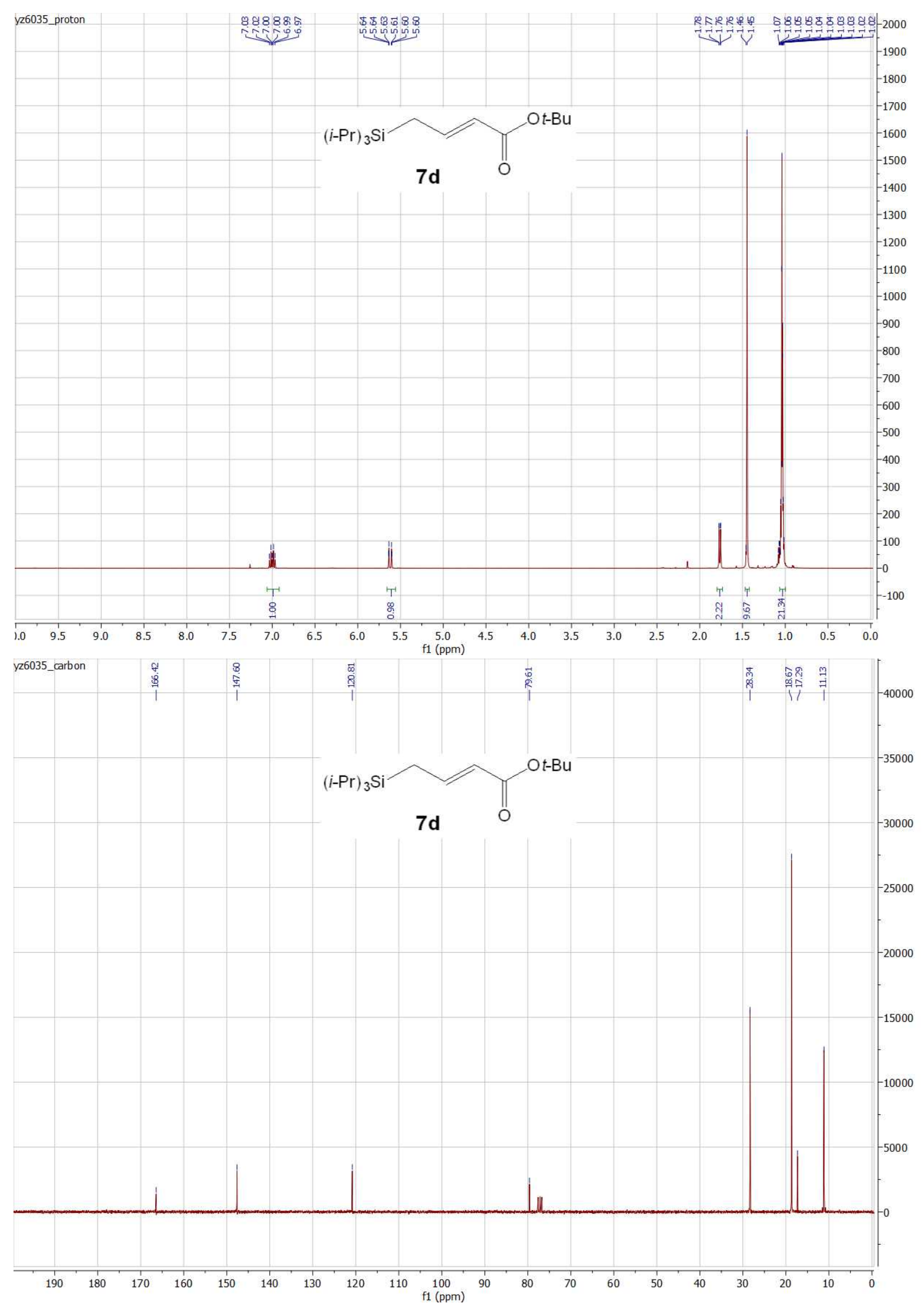




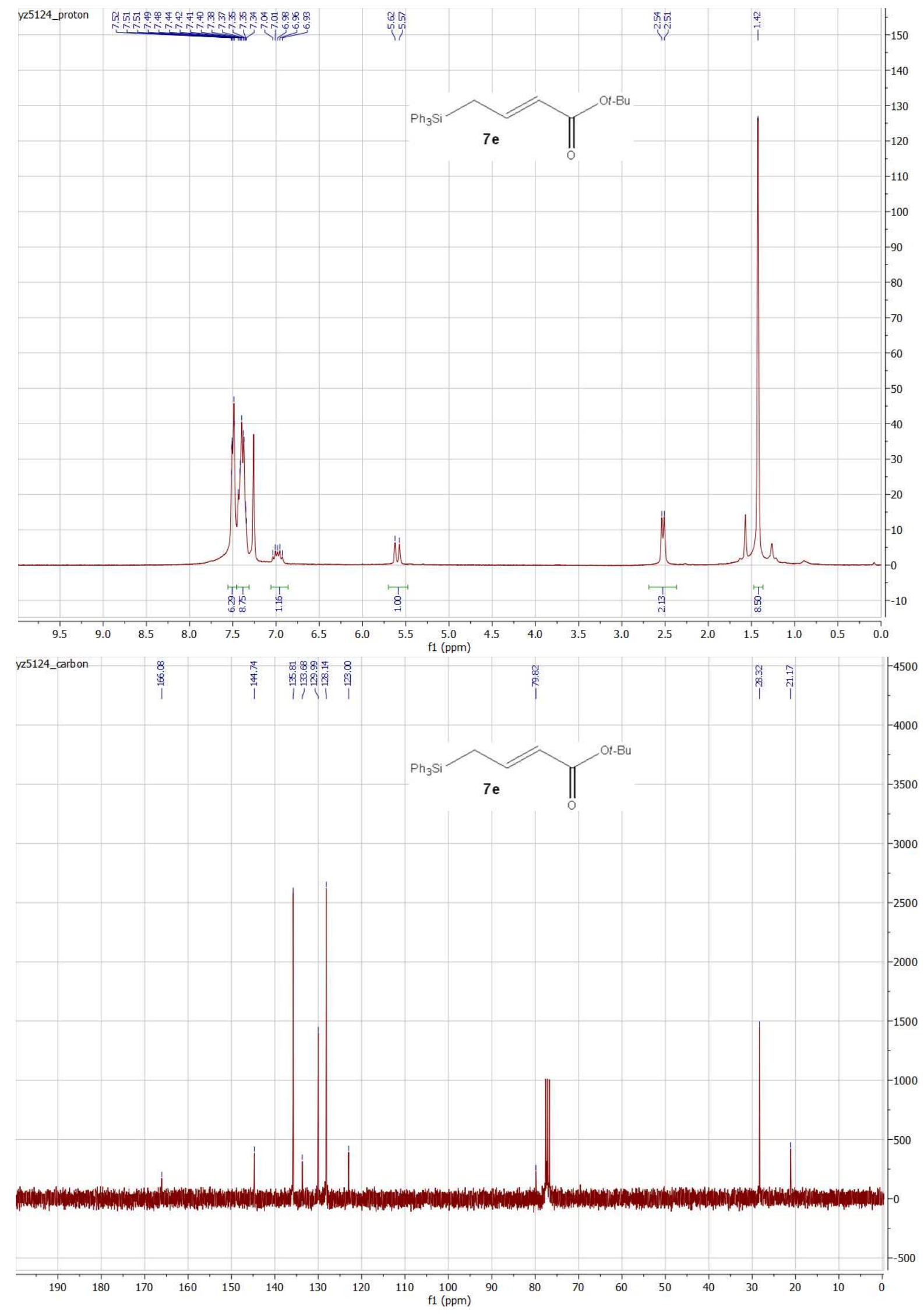




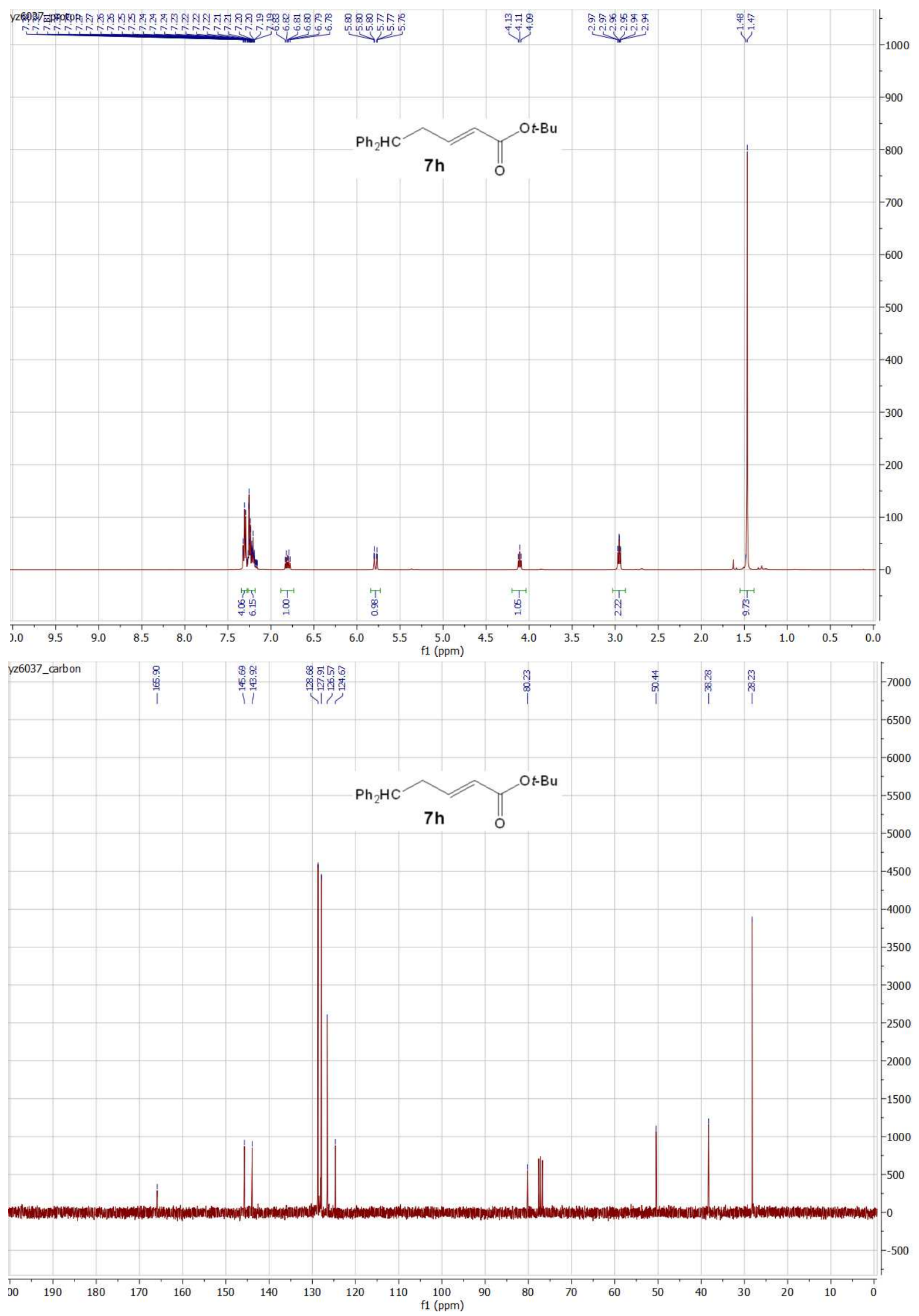



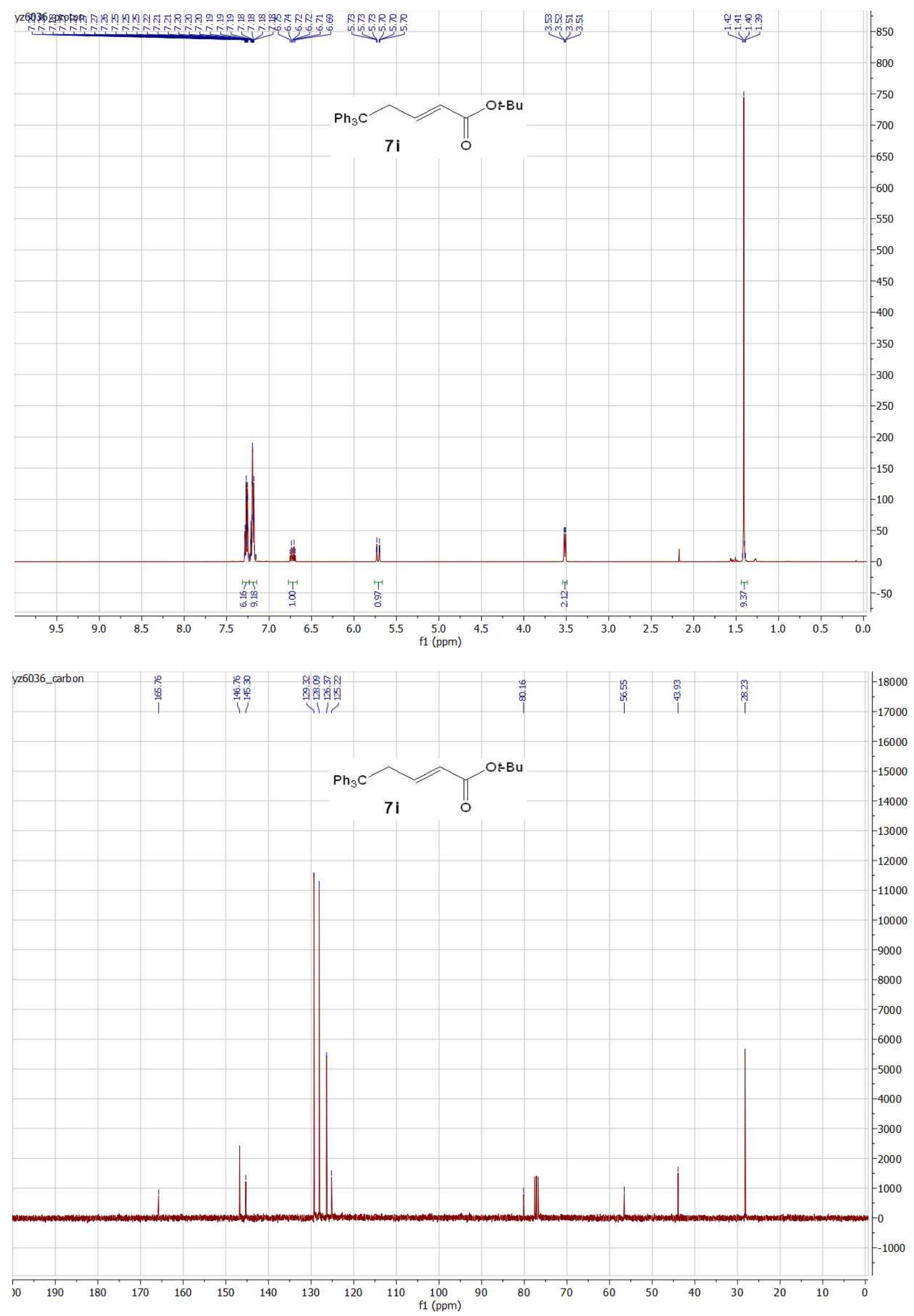

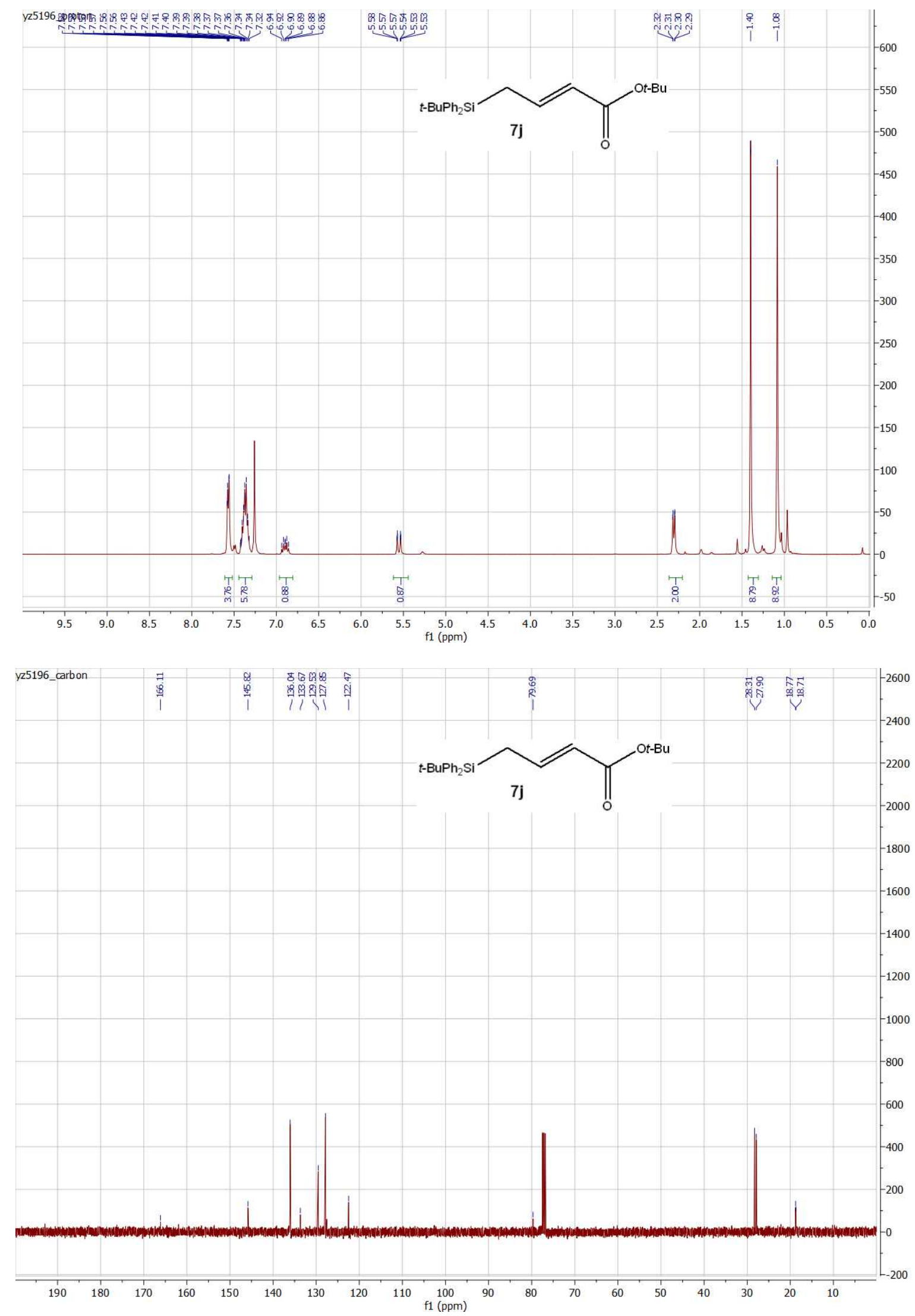

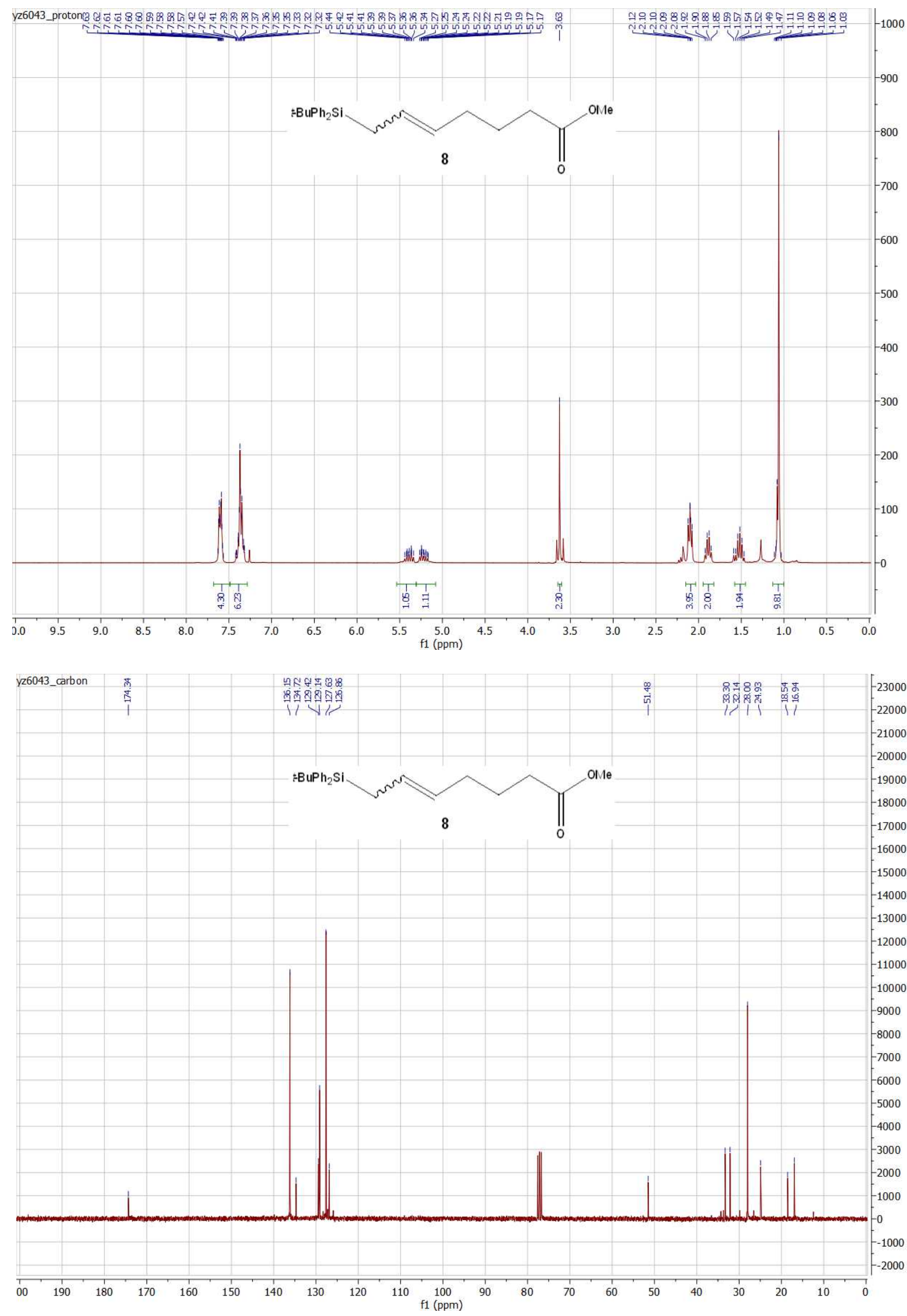

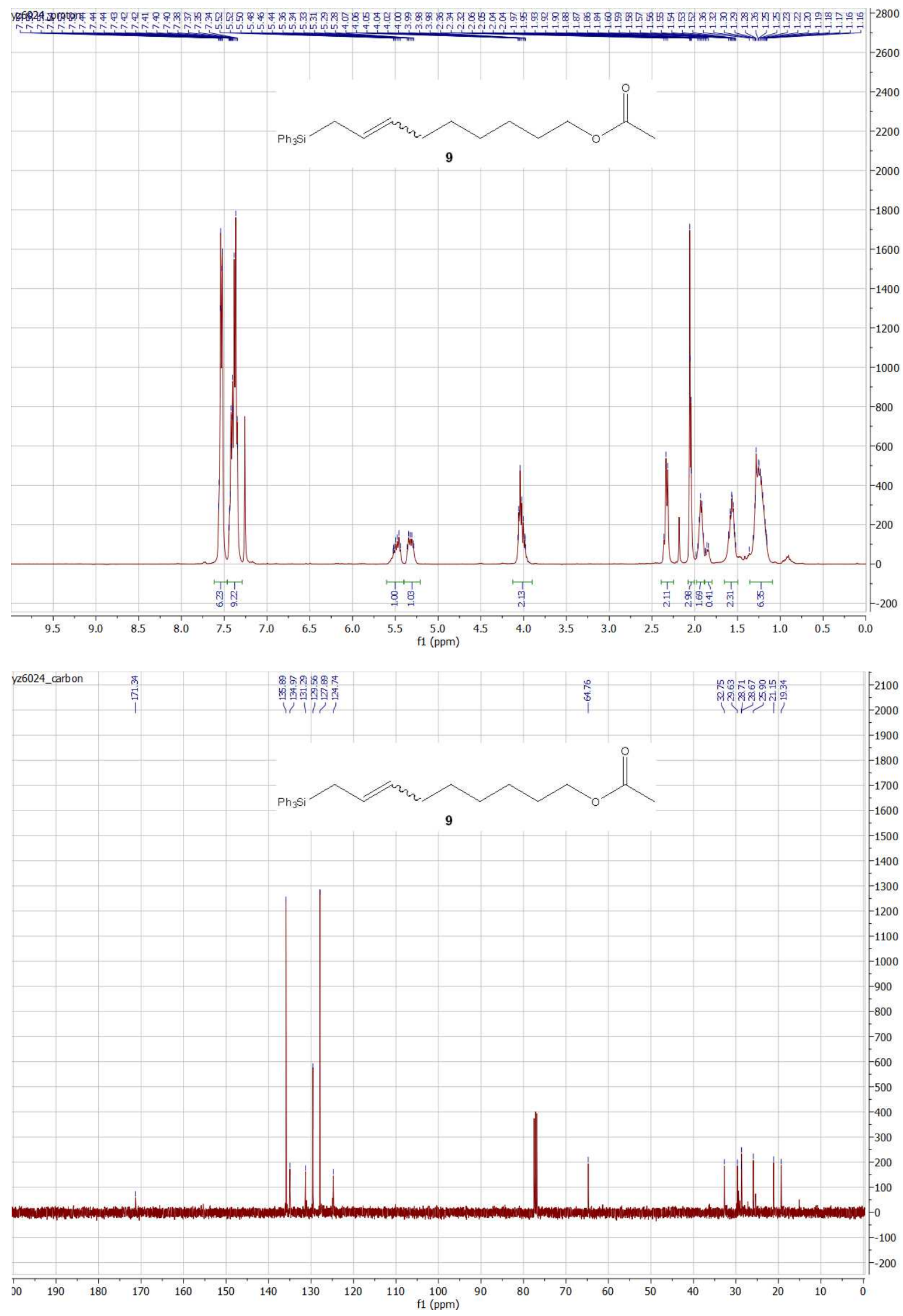

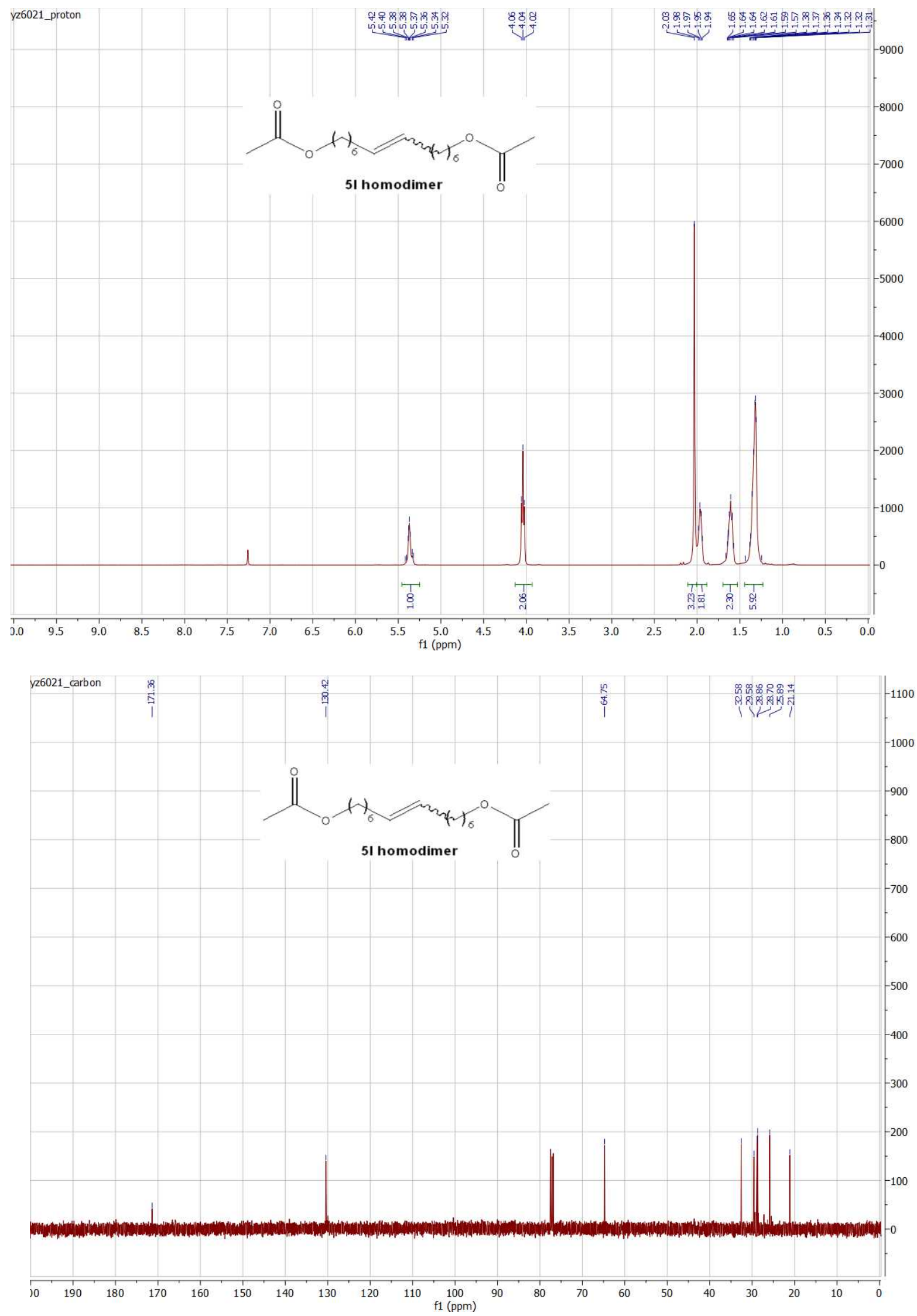


\section{J. References}

1. Leuthausser, S.; Schmidts, V.; Thiele, C. M.; Plenio, H., pi-face donor properties of N-heterocyclic carbenes in Grubbs II complexes. Chem-Eur J 2008, 14 (18), 5465-5481. 2. Ishiyama, T.; Murata, M.; Miyaura, N., Palladium(O)-Catalyzed Cross-Coupling Reaction of Alkoxydiboron with Haloarenes - a Direct Procedure for Arylboronic Esters. $J$ Org Chem 1995, 60 (23), 7508-7510.

3. Schwartz, E. B. K., C. B.; Cram, D. J., , 6 New Saddle-Shaped Hosts Based on Fused Dibenzofuran Units. J Am Chem Soc 1992, 114 (27), 10775-10784.

4. Jiang, X.; Liu, B.; Lebreton, S.; Brabander, J. K., Total synthesis and structure revision of the marine metabolite palmerolide A. J Am Chem Soc 2007, 129 (20), 6386-7. 